\title{
Revised classification scheme of phytoplasmas based on RFLP analyses of 16S rRNA and ribosomal protein gene sequences
}

\author{
Ing-Ming Lee, ${ }^{1}$ Dawn E. Gundersen-Rindal, ${ }^{2}$ Robert E. Davis ${ }^{1}$ \\ and Irena M. Bartoszyk ${ }^{1}$
}

\author{
Author for correspondence: Ing-Ming Lee. Tel: + 1301504 6024. Fax: + 13015045449. \\ e-mail: imlee asarr.arsusda.gov
}
1,2 Molecular Plant Pathology Laboratory', BIdg 011A, Rm 252, BARC West, and Insect Biocontrol Laboratory², USDA, ARS, Beltsville, MD 20705, USA

\begin{abstract}
RFLP analyses of 165 rDNA nested PCR products from 34 phytoplasma strains with 17 restriction enzymes delineated distinct pattern types. Based on similarity coefficients derived from RFLP analyses, the 34 representative phytoplasma strains were differentiated into 14 major groups (termed $16 \mathrm{Sr}$ groups) and 32 sub-groups. The similarity coefficients of RFLP patterns between distinct groups were $90 \%$ or below. By including additional groups and sub-groups from which RFLP analyses were not performed but for which 165 rDNA sequence data were available to predict restriction sites, a total of 14 groups and 41 sub-groups were proposed. By combined RFLP analyses of 165 rRNA and ribosomal protein gene sequences, thus far, a total of 46 subgroups have been recognized. The phytoplasma 16Sr groups were consistent with the phylogenetic groups (subclades) defined by phylogenetic analysis of near-full-length 165 rRNA gene sequences, indicating that the RFLP-based groups are phylogenetically valid. The approach using RFLP analyses of PCRamplified 165 rDNA (and ribosomal protein gene sequences) provides a simple, reliable and rapid means for differentiation and classification of unknown phytoplasmas.
\end{abstract}

Keywords: phytoplasma classification, RFLP, 16S rRNA, ribosomal protein, mycoplasma-like organism

\section{INTRODUCTION}

Phytoplasmas, formerly called mycoplasma-like organisms, are associated with diseases in several hundred plant species $(101,126)$. Thus far, none has been cultured in vitro (77). Until the last decade, differentiation and classification of uncultured phytoplasmas relied primarily on their biological properties, such as specificity of plant and insect hosts, and symptomatology of affected plants $(15-18,35,39,43$, $70)$. The determination of biological properties has often been time-consuming, laborious and sometimes unreliable $(77,78)$. The less laborious molecular-based analyses introduced in the last decade have proved to be more accurate and reliable for identification of phytoplasmas $(13,77)$. The use of molecular probes,

Abbreviations : $16 \mathrm{Sr}$, 165 rRNA; rp, ribosomal protein; ICSB, International Committee on Systematic Bacteriology. phytoplasma-specific cloned DNA and monoclonal antibodies have made it possible to classify phytoplasmas on the basis of DNA-DNA homology and serological data $(6,11-14,19,20,25-27,30,32,34,53$, $56,57,64,67,69,72,76-81,91,100,103,120,122)$. For example, based on dot- and Southern-hybridization analyses using cloned phytoplasma DNA probes, several distinct phytoplasma strain clusters have been recognized $(32,53,56,67-69,72,76,78-81,100,103)$. However, the sensitivity of these types of molecular probes was insufficient for many phytoplasmas associated with woody plants, in which phytoplasma concentrations are relatively low. The development of PCR assays using specific primers based on cloned phytoplasma DNA sequences allowed a more sensitive means for phytoplasma detection $(31,34,36,44,52$, $54,55,60,78,80,92,110,113)$.

Recently, phylogenetic analyses based on 16S rRNA and ribosomal protein gene sequences have revealed that the uncultured phytoplasmas form a large discrete 
I.-M. Lee and others

Table 1. Classification of phytoplasmas based on RFLP (or putative restriction site) analyses of $16 \mathrm{~S}$ rRNA and ribosomal protein gene sequences

\begin{tabular}{|c|c|c|c|c|c|c|}
\hline $\begin{array}{l}16 \mathrm{Sr} \\
\text { group }\end{array}$ & Strain & Original source & 16Sr-rp sub-group & $\begin{array}{l}\text { Accession no. } \\
\quad(16 \mathrm{Sr})\end{array}$ & $\begin{array}{l}\text { Accession no. } \\
\text { (rp) }\end{array}$ & Reference \\
\hline \multicolumn{7}{|c|}{ 16SrI (Aster yellows group) } \\
\hline $\mathrm{I}-\mathrm{A}$ & Tomato big bud BB & Tomato: Arkansas & $16 \mathrm{SrI}-\mathrm{A}(\mathrm{rp}-\mathrm{A})$ & $\mathrm{L} 33760$ & L27004 & 23,78 \\
\hline $\mathrm{I}-\mathrm{A}$ & New Jersey aster yellows NJAY & Lettuce: New Jersey & $16 \mathrm{SrI}-\mathrm{A}(\mathrm{rp}-\mathrm{A})$ & & & 78,91 \\
\hline I-A & Aster yellows AY27 & Aster: Canada & $16 \mathrm{Srl}-\mathrm{A}(\mathrm{rp}-\mathrm{A})$ & & & 78 \\
\hline $\mathrm{I}-\mathrm{A}$ & Eastern aster yellows NAY & Lettuce: Canada & $16 \mathrm{Srl}-\mathrm{A}(\mathrm{rp}-\mathrm{A})$ & & & 78 \\
\hline I-A & Periwinkle little leaf $\mathrm{CNI}$ & Periwinkle: Connecticut & $16 \mathrm{Srl}-\mathrm{A}(\mathrm{rp}-\mathrm{A})$ & & & 30,78 \\
\hline $\mathrm{I}-\mathrm{A}$ & Oklahoma aster yellows OKAYI & Lettuce: Oklahoma & $16 \mathrm{SrI}-\mathrm{A}(\mathrm{rp}-\mathrm{A})$ & & & 35. 78 \\
\hline $\mathrm{I}-\mathrm{B}$ & Michigan aster yellows MIAY & Evening primrose: Michigan & $16 \mathrm{Srl}-\mathrm{B}(\mathrm{rp}-\mathrm{B})$ & M30970 & $\mathrm{M} 77470$ & 88.89 \\
\hline I-B & Maryland aster yellows AY1 & Periwinkle: Maryland & $16 \mathrm{Srl}-\mathrm{B}(\mathrm{rp}-\mathrm{B})$ & L33767 & & 78 \\
\hline $1-B$ & American aster yellows AAY & Periwinkle: Florida & & $\mathrm{X} 68373$ & & 121 \\
\hline I-B & Dwarf aster yellows DAY & Clover: California & & & & 78 \\
\hline $\mathrm{I}-\mathrm{B}$ & Western aster yellows SAY & Celery: California & $16 \mathrm{Srl}-\mathrm{B}(\mathrm{rp}-\mathrm{B})$ & M 86340 & & 78 \\
\hline $1-B$ & Aster yellows OKAY3 & Carrot: Okalahoma & 16 Srl-B(rp-B) & & & 35,78 \\
\hline $\mathrm{I}-\mathrm{B}$ & Western aster yellows TLAY & Potato: California & & & & 78 \\
\hline I-B & Hydrangea phyllody $\mathrm{HyPH} 1$ & Hydrangea: Italy & $16 \mathrm{SrI}-\mathrm{B}(\mathrm{rp}-\mathrm{K})$ & & & 134 \\
\hline $\mathrm{I}-\mathrm{B}$ & Chrysanthemum yellows $\mathrm{CY}$ & Chrysanthemum: Italy & & & & 6,78 \\
\hline I-B & Onion yellows $\mathrm{OAY}(\mathrm{OA})$ & Onion: Japan & & D12569 & & 105 \\
\hline $1-B$ & European aster yellows EAY & Aster: Gemany & & & & 134 \\
\hline $\mathrm{I}-\mathrm{B}$ & Aster yellows-Koolsard KD & Cabbage: UK & & & & 134 \\
\hline $\mathrm{I}-\mathrm{B}$ & Aster yellows-Cactus CC & Cactus: UK & & & & 134 \\
\hline I-B & Primula yellows PY & Primula: Germany & & & & 134 \\
\hline $\mathrm{I}-\mathrm{B}$ & Gladiolus yellows GLY & Gladiolus: UK & & & & 134 \\
\hline $\mathrm{J}-\mathrm{B}$ & Hydrangea virescence & Hydrangea: Belgium & & & & 134 \\
\hline $1-B$ & Mitsuba witches'-broom JHW & Cryptotaenia: Japan & & & & 107 \\
\hline $\mathrm{I}-\mathrm{B}$ & Garland chrysanthemum WB GCW & Chrysanthemum coronarium: Japan & & & & 107 \\
\hline $\mathrm{I}-\mathrm{B}$ & Eggplant dwarf ED & Eggplant: Japan & & & & 107 \\
\hline $\mathrm{I}-\mathrm{B}$ & Tomato yellows TY & Tomato: Japan & & & & 107 \\
\hline $\mathrm{I}-\mathrm{B}$ & Marguerite yellows MY & Chrysanthemum frutescens: Japan & & & & 107 \\
\hline $\mathrm{I}-\mathrm{B}$ & Ipomoea witches'-broom IOB & Ipomoea sp.: Taiwan & $16 \mathrm{SrI}-\mathrm{B}(\mathrm{rp}-\mathrm{F})$ & & & 83 \\
\hline I-B & Maize bushy stunt MBS & Corn: Ohio, Mexico & $16 \mathrm{SrI}-\mathrm{B}(\mathrm{rp}-\mathrm{L})$ & & & 2652,83 \\
\hline $1-B$ & Mulberry dwarf MD & Mulberry: Japan, China & & & & 105 \\
\hline $\mathrm{I}-\mathrm{C}$ & Clover phyllody $\mathrm{CPh}$ & Clover: Canada & $16 \mathrm{Srl}-\mathrm{C}(\mathrm{rp}-\mathrm{C})$ & L 33762 & & 78 \\
\hline $\mathrm{I}-\mathrm{C}$ & Strawberry green petal SGP & Strawberry: Canada & $16 \mathrm{SrI}-\mathrm{C}(\mathrm{rp}-\mathrm{C})$ & & & 78 \\
\hline $\mathrm{I}-\mathrm{C}$ & Ranunculus phyllody RPh & Ranunculus: Italy & $16 \mathrm{SrI}-\mathrm{C}(\mathrm{rp}-\mathrm{C})$ & & & 48 \\
\hline $\mathrm{I}-\mathrm{D}$ & Paulownia witches'-broom PaWB & Paulownia: Taiwan & $16 \mathrm{Srl}-\mathrm{D}(\mathrm{rp}-\mathrm{D})$ & & & 78 \\
\hline $\mathrm{I}-\mathrm{E}$ & Blueberry stunt BBS1 BBS3 & Blueberry: Michigan, Arkansas & $16 \mathrm{SrI}-\mathrm{E}(\mathrm{rp}-\mathrm{E})$ & & & 78 \\
\hline $\mathrm{I}-\mathrm{F}$ & Apricot chlorotic leaf roll ACLR-AY & Apricot: Spain & & $\mathrm{X} 68383$ & & 114 \\
\hline I & Grey dogwood witches'-broom GD1 & Grey dogwood: USA & $16 \mathrm{SrI}(\mathrm{rp}-\mathrm{M})$ & & & 46 \\
\hline \multicolumn{7}{|c|}{ 16Srll (Peanut WB group) } \\
\hline II-A & Peanut witches'-broom PnWB & Peanut: Taiwan & & L33765 & & 83 \\
\hline $\mathrm{Il}-\mathrm{A}$ & Sweet potato witches'-broom SPWB & Sweet potato: Taiwan & & $\mathrm{L} 33770$ & & 83 \\
\hline $\mathrm{II}-\mathrm{A}$ & Sunhemp witches'-broom SUNHP & Sunhemp: Thailand & & X76433 & & 115 \\
\hline II-B & $\begin{array}{l}\text { Witches'-broom of lime WBDL } \\
\text { 'Cadidatus Phytoplasma aurantifolia' }\end{array}$ & Lime: Arabic Peninsula & & U15442 & & 145 \\
\hline $\mathrm{II}-\mathrm{C}$ & Faba bean phyllody FBP & Faba bean: Sudan & & $\mathrm{X} 83432$ & & 115 \\
\hline II-D & Sweet potato little leaf SPLL & Sweet potato: Australia & & & & 41 \\
\hline \multicolumn{7}{|c|}{ 16SrIII (X-disease group) } \\
\hline III-A & $\mathrm{X}$-disease CX & Peach: Canada & $16 \mathrm{Sr}+1 \mathrm{II}-\mathrm{A}(\mathrm{rp}-\mathrm{A})$ & L33733 & L27016 & 81,83 \\
\hline III-A & $\mathrm{X}$-disease WX & Peach : California & $16 \mathrm{SrlII}-\mathrm{A}(\mathrm{rp}-\mathrm{B})$ & L04682 & L27047 & 81,83 \\
\hline III-A & Peach yellow leaf roll PYLR & Peach : California & $16 \mathrm{SrlII}-\mathrm{A}(\mathrm{rp}-\mathrm{B})$ & & & 48 \\
\hline [I]-A & $\mathrm{X}$-disease $\mathrm{CCX}$ & Choke cherry: New York & 16SrlII-A(rp-B) & & & 48 \\
\hline III-B & Clover yellow edge CYE & Clover: Canada & 16 SrIII-B(rp-C) & L33766 & L27019 & 81,83 \\
\hline III-B & Vaccinium witches'-broom VAC & Vaccinium: Germany & & $\times 76430$ & & 114,121 \\
\hline III-B & Tsuwabuki witches'-broom TW & Farfugium: Japan & & D 12580 & & 107 \\
\hline 111-B & Gentian witches'-broom GW & Gentian: Japan & & & & 107 \\
\hline $\mathrm{III}-\mathrm{C}$ & Pecan bunch PB & Pecan: Georgia & 16 SrIII-C(rp-G) & & & 48 \\
\hline III-D & Goldenrod yellows GRY (GR1) & Goldenrod: New York & 16SrIII-D(rp-E) & & & 45,48 \\
\hline III-E & Spiraea stunt SP1 & Spiraea: New York & 16 SrllI-E(rp-F) & & & 45,48 \\
\hline III-F & Milkweed yellows MWY (MW1) & Milkweed: New york & 16 SrIII-F(rp-D) & & & 45,48 \\
\hline III-G & Walnut witches-broom WWB & Walnut: Georgia & $16 \mathrm{SrIII-G(rp-B)}$ & & & 12,45 \\
\hline III-H & Poinsettia branch-inducing PoiBI & Poinsettia: US & & & & 84 \\
\hline \multicolumn{7}{|c|}{ 16SrIV (Coconut lethal yellows group) } \\
\hline IV-A & Coconut lethal yellows LY, LY3 & Palm: Florida & & U18747 & & $53-55$ \\
\hline IV-B & Yucatan coconut lethal decline LDY & Palm: Mexico & & U18753 & & 54 \\
\hline IV-C & Tanzanian coconut lethal decline LDT & Palm: Africa & & $\mathrm{X} 80117$ & & 54 \\
\hline \multicolumn{7}{|c|}{ 16SrV (Elm' yellows group) } \\
\hline $\mathrm{V}-\mathrm{A}$ & Elm yellows EY1 & Elm: New York & $16 \mathrm{SrV}-\mathrm{A}(\mathrm{rp}-\mathrm{A})$ & L33763 & $\mathrm{L} 27022$ & 80 \\
\hline V-A & Elm yellows ItaEY & Elm: Italy & & & & 75,80 \\
\hline $\mathrm{V}-\mathrm{A}$ & Elm witches'-broom ULW & Elm: France & & X68376 & & 100.121 \\
\hline V-B & Cherry lethal yellows CLY & Cherry: China & $16 \mathrm{SrV}-\mathrm{B}(\mathrm{rp}-\mathrm{B})$ & & & 86,144 \\
\hline $\mathrm{V}-\mathrm{B}$ & Jujube witches'-broom JWB & Jujube: China & $16 \mathrm{SrV}-\mathrm{B}(\mathrm{rp}-\mathrm{C})$ & & & 144 \\
\hline $\mathrm{V}-\mathrm{C}$ & Rubus stunt RS & Rubus: Italy & & & & 75 \\
\hline $\mathrm{V}-\mathrm{C}$ & Alder yellows AlY & Alder: Germany & & & & 100 \\
\hline
\end{tabular}


Table 1. (cont.)

\begin{tabular}{|c|c|c|c|c|c|c|}
\hline $\begin{array}{l}16 \mathrm{Sr} \\
\text { group }\end{array}$ & Strain & Original source & 16Sr-rp sub-group & $\begin{array}{l}\text { Accession no. } \\
\quad(16 \mathrm{Sr})\end{array}$ & $\begin{array}{l}\text { Accession no. } \\
\text { (rp) }\end{array}$ & Reference \\
\hline V-C & Spartium witches'-broom (EY) & Spartium: Italy & & & & 97 \\
\hline $\mathrm{V}-\mathrm{C}$ & Eucalyptus little leaf & Eucalyptus: Italy & & & & 97 \\
\hline $\mathrm{V}-\mathrm{C}$ & Flavescence dorée FD & Grapevine: France & $16 \mathrm{SrV}-\mathrm{C}(\mathrm{rp}-\mathrm{D})$ & $X 76560$ & & $20-22$ \\
\hline \multicolumn{7}{|c|}{ 16SrVI (Clover proliferation group) } \\
\hline VI-A & Clover proliferation $\mathrm{CP}$ & Clover: Canada & & L33761 & L27011 & 34,79 \\
\hline VI-A & Periwinkle virescence VR, BLTVA & Periwinkle: California & & & & 79,122 \\
\hline VI-A & Tomato big bud TBB & Tomato: California & & & & 122 \\
\hline VI-A & Pot:sto witches'-broom PWB & Potato: Canada & & & & 34,79 \\
\hline Vl-A & Potitto yellows & Potato: North Dakota & & & & This study \\
\hline \multicolumn{7}{|c|}{ 16SrVII (Ash yellows group) } \\
\hline VII-A & Ash yellows AshY & Ash: New York & & $\mathrm{X} 68339$ & L26999 & 32,127 \\
\hline VII-A & Lilac witches'-broom LiWB & Lilac: New York & & & & 57 \\
\hline \multicolumn{7}{|c|}{ 16SrVIII (Loofah witches'-broom group) } \\
\hline VIIII-A & Loofah witches'-broom LfWB & Loofah: Taiwan & & L33764 & L27027 & 83 \\
\hline \multicolumn{7}{|c|}{ 16SrIX (Pigeon pea witches'-broom group) } \\
\hline IX-A & Pigeon pea witches'-broom PPWB & Pigeon pea: Florida & & U18763 & L27036 & 56 \\
\hline \multicolumn{7}{|c|}{ 16SrX (Apple proliferation group) } \\
\hline $\mathrm{X}-\mathrm{A}$ & Apple proliferation AT, AP-A & Apple: Germany, Italy & & $\mathrm{X} 68375$ & L27994 & $37,68,93$ \\
\hline $\mathrm{X}-\mathrm{B}$ & Apricol chlorotic leaf roll ACLR (Ita) & Apricot: Italy & & & & 7,74 \\
\hline $\mathrm{X}-\mathrm{B}$ & Plum leptonecrosis PLN & Japanese plum: Italy & & & & 74 \\
\hline $\mathrm{X}-\mathrm{B}$ & European stone fruit yellows PPER & Peach: Germany & & $\mathrm{X} 68374$ & & 114 \\
\hline $\mathrm{X}-\mathrm{C}$ & Pear decline PD & Pear: Italy, UK & & & & $7,24,74$ \\
\hline $\mathrm{X}-\mathrm{D}$ & Spartium witches'-broom SPAR & Spartium: Italy & & X92869 & & 97 \\
\hline$X-E$ & $\begin{array}{l}\text { Black alder witches'-broom BAWB } \\
\text { (Buckthorn witches'-broom BWB) }\end{array}$ & Black alder (Buckthorn): Germany & & $\times 76431$ & & 121 \\
\hline \multicolumn{7}{|c|}{ 16SrXI (Rice yellow dwarf group) } \\
\hline $\mathrm{XI}-\mathrm{A}$ & Rice yellow dwarf RYD & Rice: Japan, India & & D12581 & & $85,103,105$ \\
\hline $\mathrm{XI}-\mathrm{B}$ & Sugarcane white leaf SCWL & Sugarcane: Thailand & & $\times 76432$ & & $85,103,105$ \\
\hline $\mathrm{XI}-\mathrm{B}$ & Sugitrane grassy shoot SCGS & Sugarcane: India & & & & 85 \\
\hline $\mathrm{XI}-\mathrm{C}$ & Leathopper-borne BVK & Psammotettix cephalotes: Germany & & X76429 & & 121 \\
\hline \multicolumn{7}{|c|}{ 16SrXII (Stolbur group) } \\
\hline XII-A & Stolbur STOL & Capsicum annum: Serbia & & $\mathrm{X} 76427$ & & 121 \\
\hline XII-A & Grapevine yellows & Grapevine: Germany & & $\mathrm{X} 76428$ & & 94,121 \\
\hline XII-A & Celery yellows CelY & Celery: Italy & & & & 134 \\
\hline XII-B & $\begin{array}{l}\text { Ausiralian grapevine yellows AUSGY } \\
\text { 'Candidatus Phytoplasma australiense' }\end{array}$ & Grapevine: Australia & & $\mathrm{L} 76865$ & & 28,109 \\
\hline $\begin{array}{l}\text { XII-B } \\
\text { 16SrXIII }\end{array}$ & $\begin{array}{l}\text { Phormium yellow leaf } \mathrm{PYL} \\
\text { (Mevican periwinkle virescence group) }\end{array}$ & New Zealand flax: New Zealand & & U43570 & & 87 \\
\hline XIII-A & Mexican periwinkle virescence MPV & Periwinkle: Mexico & & & & 48 \\
\hline XIII-B & Strawberry green petal (Florida) & Strawberry: Florida & & & & 61,62 \\
\hline $16 \mathrm{SrXIV}$ & (Bermudagrass white leaf group) & & & & & \\
\hline XIV-A & Bermudagrass white leaf $B G W L$ & Bermudagrass: Thailand & & & & 85 \\
\hline $\mathrm{XIV}-\mathrm{A}$ & Annual blue grass white leaf $\mathrm{ABGWL}$ & Poa annua: Italy & & & & 85 \\
\hline
\end{tabular}

monophyletic clade within the class Mollicutes $(49,64$, $65,71,88-90,105,115,119,121,130)$. The phylogenetic interrelationships among representative phytoplasmas provide a basis for establishing a phylogenetically valid classification $(49,105,121)$. PCR using phytoplasma group-specific or universal primers derived from conserved $16 \mathrm{~S}$ rRNA gene sequences has provided, for the first time, a sensitive means for detection of a broad array of phytoplasmas from infected plants or insect vectors $(1-3,24,29,33,46,47$, $51,74,83,93,104,114,128)$. By direct sequence analysis or RFLP analysis of PCR-amplified $16 \mathrm{~S}$ rDNA, the phytoplasmas detected can be differentiated and classified $(83,114,118)$. Several classification systems have been proposed either directly, based on sequence analysis or indirectly, by RFLP analysis of PCR-amplified 16S rDNA. Classification by RFLP analysis has provided a simple and rapid method that can be used to differentiate and identify a large number of unclarified phytoplasmas in a rela- tively short period of time. However, in some cases, the phytoplasma groups classified on the basis of RFLP analyses using few restriction enzymes were not always consistent with groups based on phylogenetic analysis of $16 \mathrm{~S}$ rRNA gene sequences $(114,121)$.

Our objective was to develop a comprehensive classification scheme based on RFLP analysis of phytoplasma $16 \mathrm{~S}$ rDNA sequences that is phylogenetically valid. On the basis of similarity coefficients of collective RFLP patterns derived by extensive RFLP analyses of PCR-amplified 16S rDNA with 15 restriction enzymes, we have previously proposed a classification scheme that comprises nine distinct phytoplasma groups (83). The grouping is consistent with the strain clusters previously identified, based on DNA-DNA homology and serological data $(32,53,56,67-69,72,78-81,100)$. Sub-groups within each group were determined, based on the dissimilarity of restriction sites identified by RFLP analyses of $16 \mathrm{~S}$ rDNA. Fourteen sub-groups 
were preliminarily identified. The classification scheme was later expanded to include one additional group and six new sub-groups $(28,45,48-50,61,62,134)$. Moreover, combined RFLP analyses of $16 \mathrm{~S}$ rDNA and ribosomal protein gene sequences were proposed for finer sub-group differentiation $(48,50)$. The subgroups delineated by this combined approach are more consistent with the subclusters identified based on DNA-DNA homology.

As many new phytoplasma strains have been identified in the last four years $(7-9,12,14,21-22,27,28,40-42$, $54,57,61,62,84-87,93-100,107,109,110,115,116$, $133-135,142,144,145)$, it has been necessary to update and expand the current scheme. The objectives of this study were to revise and further expand the current RFLP-based classification scheme into a comprehensive classification system in which representative strains of known phytoplasmas were included and to validate the phytoplasma classification by parallel phylogenetic analysis using full-length $16 \mathrm{~S}$ rRNA gene sequences.

\section{METHODS}

Sources of phytoplasma strains. Phytoplasma strains used in this study are listed in Table 1. Total nucleic acid was extracted from freshly collected or oven-dried tissues according to a previously described procedure (80).

Primers and PCR conditions. The two universal primer pairs $\mathrm{R} 16 \mathrm{mF} 2 / \mathrm{R} 16 \mathrm{mR} 1$ and $\mathrm{R} 16 \mathrm{~F} 2 \mathrm{n} / \mathrm{R} 16 \mathrm{R} 2$, were previously designed based on $16 \mathrm{~S}$ rRNA gene sequences and used for amplification of phytoplasma $16 \mathrm{~S}$ rDNA $(47,83)$. Nested $\mathrm{PCR}$ with the primer pair R16mF2/R16mR1, followed by R16F2n/R16R2, was used to detect putative phytoplasmas from each of the nucleic acid preparations. Nested PCR can also be performed by using the universal primer pair $\mathrm{P} 1 / \mathrm{P} 7$ (118) followed by $\mathrm{R} 16 \mathrm{~F} 2 \mathrm{n} / \mathrm{R} 16 \mathrm{R} 2$. The primer pair $\mathrm{rpF} 1 /$ rpR1, designed by Lim \& Sears (90) was used to amplify a segment of the ribosomal protein gene operon from members of phytoplasma 16S rRNA (16Sr) group I (aster yellows and related phytoplasmas) and group III (X-disease and related phytoplasmas). Two primer pairs, $r p(\mathrm{~V}) \mathrm{FI} / \mathrm{rpRl}$ and $\mathrm{rp}(\mathrm{V}) \mathrm{F} 2 / \mathrm{rpR} 1$ were used to amplify ribosomal protein gene sequences from members of $16 \mathrm{Sr}$ group $\mathrm{V}$ (elm yellows and related phytoplasmas). The oligonucleotide sequences of the primers used in this study are: $\mathrm{R} 16 \mathrm{mF} 2,5^{\prime}$-CATGCAAGTCGAACGA-3'; R16mR1， 5'-CTTAACCCCAATCATCGAC-3'; R16F2n, 5'-GAAACGACTGCTAAGACTGG-3'; R16R2, 5'-TGACGGGCGGTGTGTACAAACCCCG-3'; rpF1, 5'-GGACATAAGTTAGGTGAATTT-3'; rpR1, 5'-ACGATATTTAGTTCTTTTTGG-3'; $\operatorname{rp}(\mathrm{V}) \mathrm{F} 1$, 5'-TCGCGGTCATGCAAAAGGCG-3'; $\operatorname{rp}(\mathrm{V}) \mathrm{F} 2,5^{\prime}$-TTGCCTCGTTTATTTCCGAGAGCTA-3'. Semi-nested PCR with $\operatorname{rp}(\mathrm{V}) \mathrm{F} 1 / \mathrm{rpR} 1$ followed by $\mathrm{rp}(\mathrm{V}) \mathrm{F} 2 / \mathrm{rpR} 1$ was used to amplify ribosomal protein gene sequences from members of $16 \mathrm{Sr}$ group $\mathrm{V}$.

For PCR amplification, 35 cycles were conducted in an automated thermocycler (Perkin Elmer DNA Thermal Cycler 480) with AmpliTaq or AmpliTaq Gold polymerase. PCR was performed as described previously (82) in mixtures containing $1 \mu$ of diluted nucleic acid preparations $(1: 30$ in sterile water), $200 \mu \mathrm{M}$ each dNTP and $0.4 \mu \mathrm{M}$ each primer. The following conditions were used: denaturation at $94{ }^{\circ} \mathrm{C}$ for 1 min ( 2 min with AmpliTaq or 12 min with AmpliTaq Gold for the first cycle), annealing for $2 \mathrm{~min}$ at $60^{\circ} \mathrm{C}\left(55^{\circ} \mathrm{C}\right.$ for second amplification in nested PCR) and primer extension for $3 \mathrm{~min}\left(10 \mathrm{~min}\right.$ in the final cycle) at $72^{\circ} \mathrm{C}$. One microlitre of diluted $(1: 30) \mathrm{PCR}$ products from the first amplification was used as the template in the second-round PCR. The PCR products $(5-10 \mu \mathrm{l})$ were analysed by electrophoresis on a $1 \%$ agarose gel followed by staining with ethidium bromide and visualization of the DNA bands with a UV transilluminator.

Phylogenetic analysis. Complete or nearly complete $16 \mathrm{~S}$ rRNA gene sequences from 42 phytoplasmas, three Acholeplasma spp. and three Anaeroplasma spp. were aligned separately by using CLUSTAL, version 5, using DNASTAR's LaserGene software (DNASTAR, Madison, WI, USA) and, if necessary, visually inspected for logical placement of gaps and manually adjusted (49). Cladistic analyses were performed with the computer program PAUP (phylogenetic analysis using parsimony), version 3.1 , written by $D$. L. Swofford (University of Illinois), on a Power Macintosh model 8100 . Uninformative characters were excluded from analyses. A phylogenetic tree was constructed by a heuristic search via random stepwise addition implementing the tree bisection and reconnection branch-swapping algorithm to find the optimal phylogenetic tree(s). Anaeroplasma abactoclasticum was selected as the out-group to root the tree. The analysis was replicated 100 times. Bootstrapping was performed to estimate the stability and support for the inferred clades.

RFLP analysis of PCR products. 16S rDNA fragments from the putative phytoplasmas amplified by PCR with the primer pair $\mathrm{R} 16 \mathrm{~F} 2 \mathrm{n} / \mathrm{R} 16 \mathrm{R} 2$, and ribosomal protein sequences amplified with the primer pair $\mathrm{rpF} 1 / \mathrm{rpR} 1$ or $\mathrm{rp}(\mathrm{V}) \mathrm{F} 2 / \mathrm{rpR} 1$ were analysed by restriction endonuclease digestion. Each PCR product (3-5 $\mu \mathrm{l}, 100-200 \mathrm{ng}$ DNA) was digested separately with some of the following restriction enzymes according to the instructions of the manufacturer: Alul, BamHI, BfaI, DraI, EcoRI, HaeIII, HhaI, HinfI, HpaI, HpaII, KpnI, RsaI, SspI, TaqI, ThaI and Tsp509I (used only for the ribosomal protein gene)(Gibco-BRL), and $M s e I$ and Sau3A I (New England Biolabs) $(50,83)$. To ensure the PCR products were fully digested, digestions were performed for a longer time than recommended by manufacturer (up to $48 \mathrm{~h}$ for $A l u \mathrm{I})$. The restriction products were then separated by electrophoresis through a 5 or $12 \%$ (for some restriction products of ribosomal protein DNA sequences) polyacrylamide gel and stained in ethidium bromide. DNA bands were visualized with a UV transilluminator (50).

For constructing a dendrogram, the R16F2n/R16R2 PCR products from 34 representative phytoplasma strains were first digested with each of the 17 restriction endonucleases listed above. The RFLP patterns (the sum result of 17 enzymes) of 34 phytoplasmas were compared and analysed by the method of Nei \& Li (106). The similarity coefficient $(F)$ of strains $x$ and $y$ was calculated as $F=2 N_{x y} /\left(N_{x}+N_{y}\right)$, in which $N_{x}$ and $N_{y}$ are the number of fragments resulting from digestions by 17 enzymes in strains $x$ and $y$, respectively, and $N_{x u}$ is the number of fragments shared by the two strains. A dendrogram was derived from a cluster analysis by using the Sahn clustering method (NTSYS-pc program, Exeter Publishing, Setauket, NY).

Putative restriction site analysis of 165 rDNA. Putative restriction site maps of $16 \mathrm{~S}$ rRNA gene sequences for phytoplasmas from which RFLP analyses were not performed in this study were generated by using the DNASTAR 
program MapDraw option (DNASTAR) (50). Sequences acquired from the GenBank database were analysed to identify the restriction recognition sequences for 17 restriction enzymes.

\section{RESULTS AND DISCUSSION}

\section{RFLP and phylogenetic analyses of 165 rDNA}

RFLP analyses of the 34 phytoplasma $16 \mathrm{~S}$ rDNAs (R16F2n/R16R2 nested PCR products) with 17 restriction enzymes identified distinct pattern types. Representative patterns of the 34 phytoplasma $16 \mathrm{~S}$ rDNAs are shown in Fig. 1 and Table 2. By using clean and specific nested-PCR products for RFLP analyses, the RFLP patterns of each representative phytoplasma strain analysed with various restriction enzymes have been shown to be consistent and absolutely reproducible. Based on similarity coefficients derived from RFLP analyses, the 34 representative phytoplasma strains were divided into 14 major groups (termed $16 \mathrm{Sr}$ groups) and 32 sub-groups (Fig. 3, Table 2). The similarity coefficients of RFLP patterns between two distinct groups were $90 \%$ or below (Table 3). By including the additional groups and sub-groups identified. based on analysis of phylogeny and putative restriction sites of $16 \mathrm{~S}$ rDNAs (data not shown) from the phytoplasmas of which RFLP analyses were not performed, a total of 14 groups and 41 sub-groups were proposed. By combined RFLP analyses of $16 \mathrm{~S}$ rRNA and ribosomal protein gene sequences, thus far, a total of 46 sub-groups [16Sr and 16Sr-rp (rp, ribosomal protein)] have been recognized. Phylogenetic analysis of near-full-length $16 \mathrm{~S}$ rRNA gene sequences from 42 diverse phytoplasmas and representative Acholeplasma species and Anaeroplasma species yield 10 trees that are equally the most parsimonious, minor differences occurring only at outermost branching taxa, one of which is shown in Fig. 4. As shown in previous studies $(49,118,121,130)$, phytoplasmas formed a large phylogenetic group more closely related to Acholeplasma palmae and Acholeplasma modicum. Within the phytoplasma clade, a total of 13 distinct phytoplasma monophyletic groups or taxa, which we designate as subclades (using lowercase Roman numerals) were recognized. Two new subclades (xii and xiii) were identified in this and previous studies $(28,87)$.

\section{Revision and expansion of the phytoplasma classification scheme}

In this study, on the basis of comprehensive RFLP or putative-restriction-site analyses of $16 \mathrm{~S}$ rDNAs (from representatives of the known phytoplasma strains), we have expanded the previous classification scheme (49, $50,82)$ to include three new major phytoplasma $16 \mathrm{Sr}$ groups (XII, stolbur group; XIII, Mexican periwinkle virescence group; and XIV, bermudagrass white leaf group) and 16 new $16 \mathrm{Sr}$ sub-groups (II-B, strain witches'-broom WBDL; II-C, faba bean phyllody
FBP; II-D, sweet potato little leaf SPLL; III-G, walnut witches'-broom WWB; III-H, poinsettia branch-inducing PoiBI; IV-B, Yucatan coconut lethal decline LDY; IV-C, Tanzanian coconut lethal decline LDT; V-B, cherry lethal yellows CLY and jujube witches'-broom JWB; V-C, rubus stunt RS, alder yellows AlY, spartium witches'-broom (EY type), eucalyptus little leaf, and flavescence dorée FD; X-C, pear decline PD; X-D spartium witches'-broom SPAR (AP type); X-E, black alder witches'-broom BAWB (new term, buckthorn witches'-broom BWB); XII-A, stolbur STOL and celery yellows CelY; XII-B, Australian grapevine yellows AUSGY and phormium yellow leaf PYL; XIII-A, Mexican periwinkle virescence MPV; and XIV-A, bermudagrass white leaf BGWL and annual blue grass white leaf ABGWL, and five new 16Sr-rp [formerly called 16Sr-(rr-rp)] subgroups: 16SrI-B(rp-K), hydrangea phyllody HyPH1; 16SrV-A(rp-A), elm yellows EY1 and elm yellows ItaEY; 16SrV-B(rp-B), cherry lethal yellows CLY; $16 \mathrm{SrV}-\mathrm{B}(\mathrm{rp}-\mathrm{C})$, jujube witches'-broom JWB; 16SrV$\mathrm{C}(\mathrm{rp}-\mathrm{D})$, flavescence dorée FD based on combined analyses of $\mathrm{rr}$ and ribosomal protein gene sequences (Table 1). A new coding system (16Sr-rp) to indicate sub-groups derived from combined analyses was used in this study. Both rRNA and ribosomal protein RFLP pattern types of a given strain were incorporated. The phytoplasma strains whose group or subgroup affiliations were revised and reassigned were: 16SrI-C(rp-C), ranunculus phyllody RPh [formerly IG(16Sr-rp)]; XII-A, stolbur STOL (formerly I-G) and celery yellows CelY (formerly I-G); XII-B, Australian grapevine yellows AUSGY (formerly I-J); III-F, milkweed yellows MW1 (formerly III-B); III-G, walnut witches'-broom WWB (formerly III-E); X-C, pear decline PD (formerly X-A); XIII-A, Mexican periwinkle virescence MPV (formerly I-I); and XIV-A, bermudagrass white leaf BGWL (formerly XI-C) and annual blue grass white leaf ABGWL (formerly XI-C). To avoid the potential confusion, sub-groups I-G, I-I, I-J and XI-C will not be used for assigning new phytoplasma strains.

Parallel phylogenetic analysis of near-full-length $16 \mathrm{~S}$ rRNA gene sequences from most of the representative phytoplasma strains indicated that the RFLP-based groups are phylogenetically valid; groups based on extensive RFLP analyses were consistent with phylogenetic groups (subclades) (Fig. 4). The extensive RFLP analyses using 17 restriction enzymes provides sufficient characters (restriction sites) for comparison among phytoplasmas. Each group and sub-group can be defined on the basis of RFLP-pattern type (Fig. 1 and Table 2). The approach, using RFLP analyses of PCR-amplified 16S rDNAs, has provided a simple and reliable means of differentiation and classification of many unknown phytoplasmas in a relatively short period of time. An uncharacterized phytoplasma can be identified and classified preliminarily by comparison of its RFLP pattern type with known pattern types of designated phytoplasma groups and sub-groups. In 

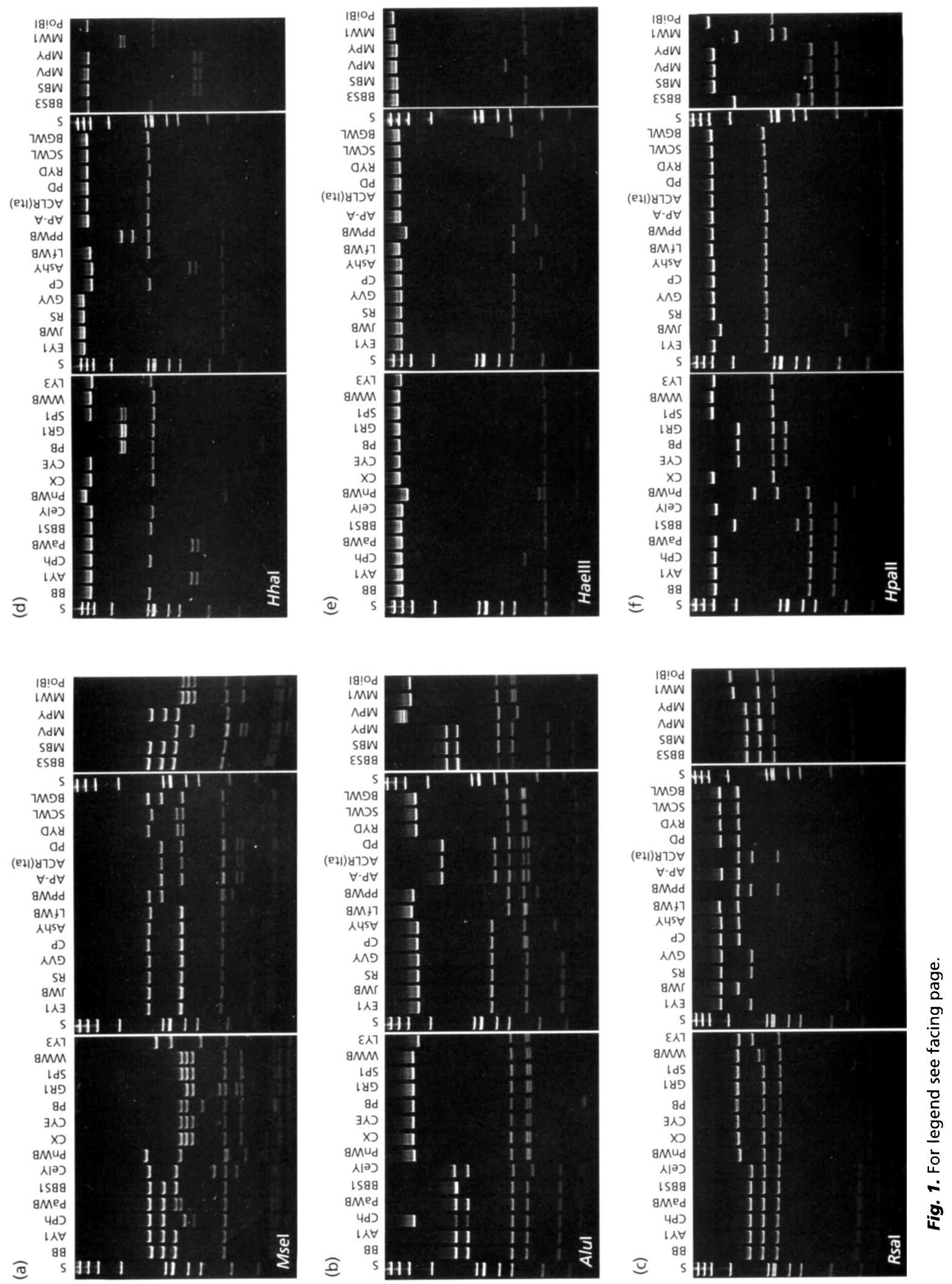

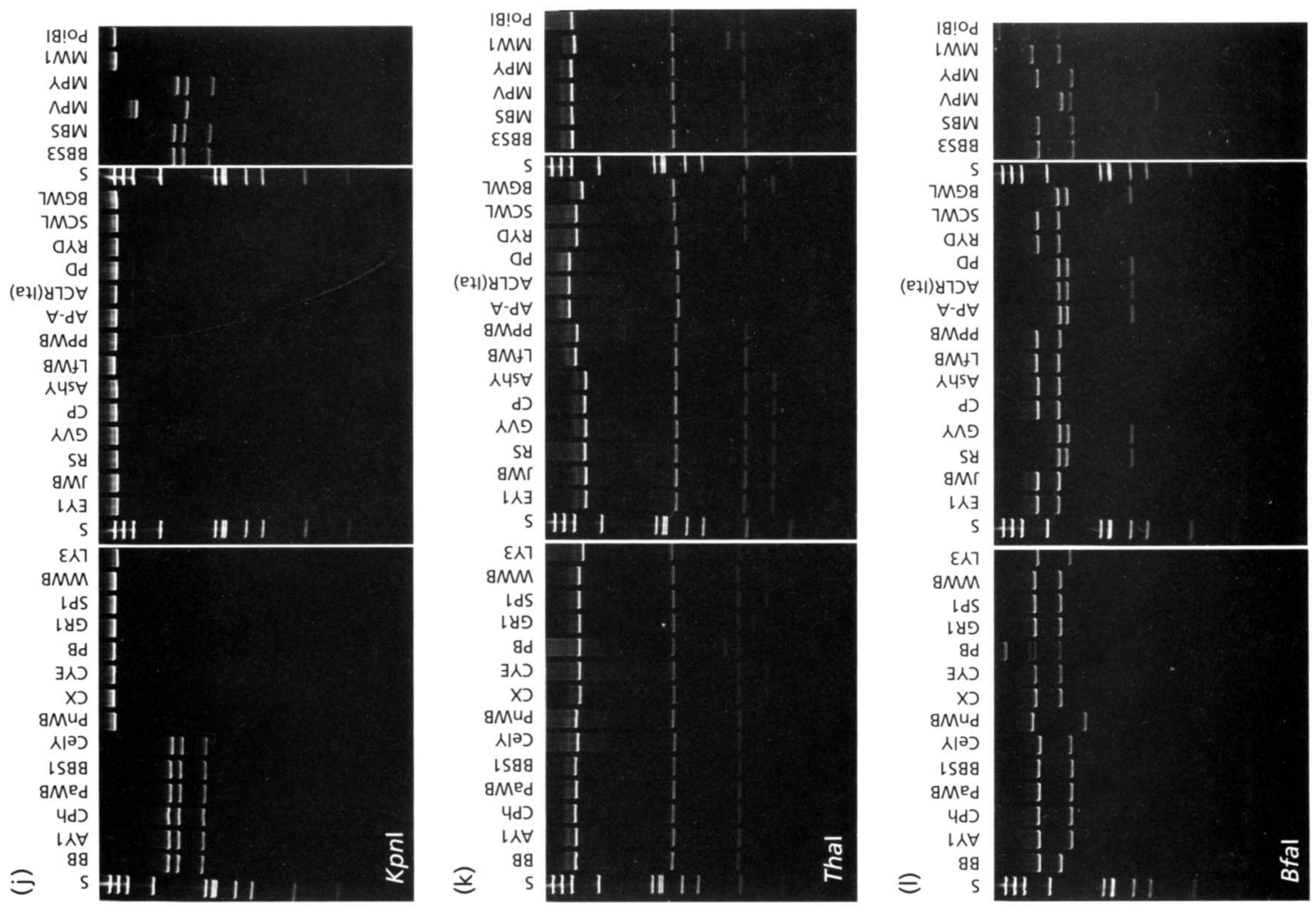

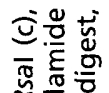

날

金要需

这这र 20 क्षि

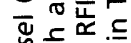

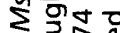
政 美空希 ชn vio ชั) ⿷匚⿳丨コ丨 응ㄷㅇㅇ 西

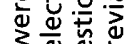

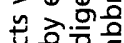
긍

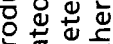

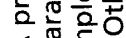
选造

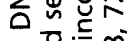
. วิڤڤ

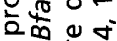
눤훼
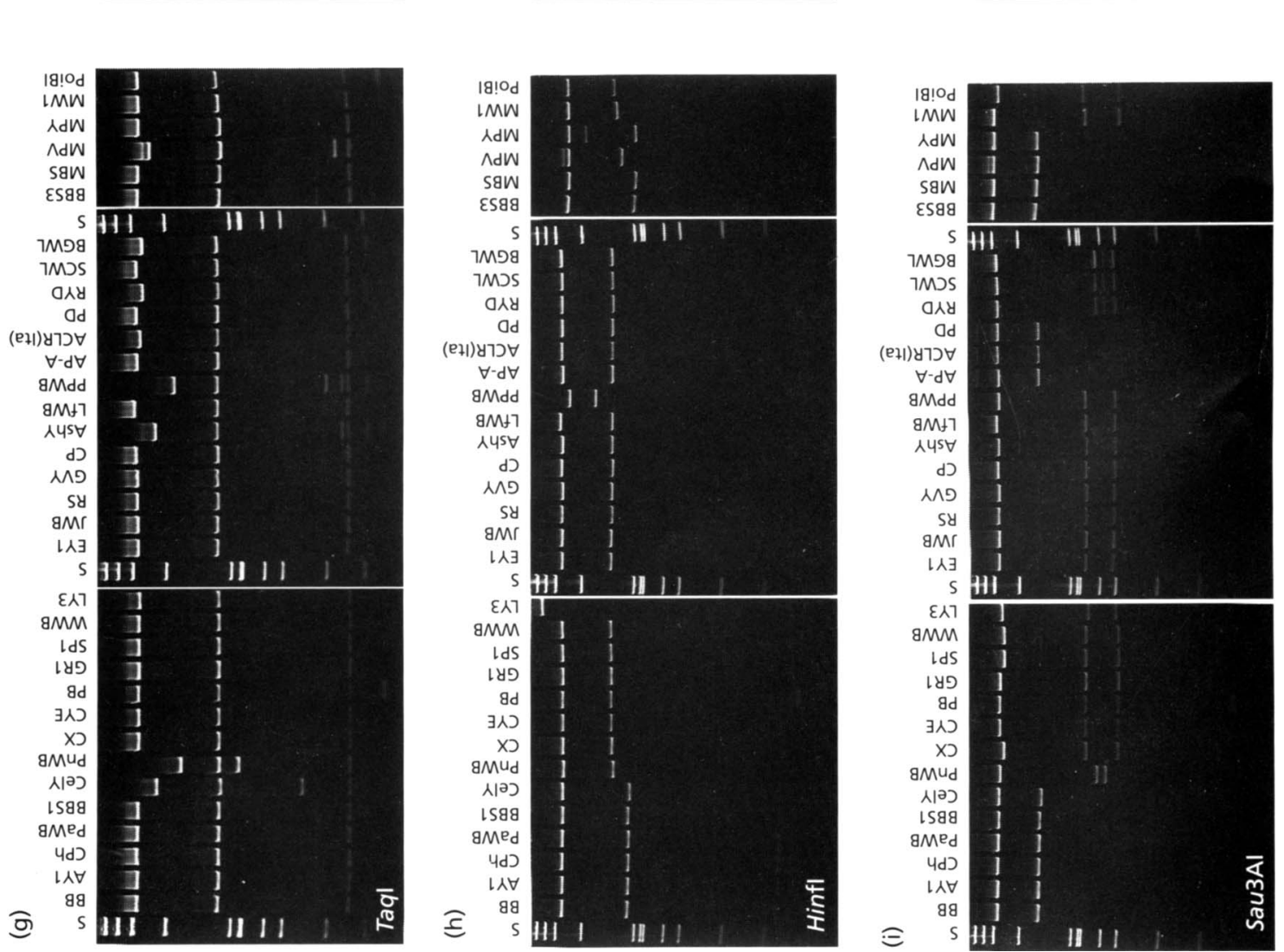

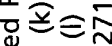

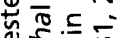

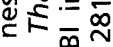
종응 둥 产敦家 蒴

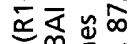
这完家文 $\sum \pi$ 는 ธิ둬ำ 。定 政 중요요

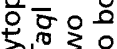
的 这高 市 $\overline{\bar{\sigma}} \frac{2}{3} \varepsilon$

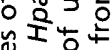
㐫的 T

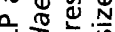
言赵言的

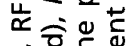
จ웡 演全 
I.-M. Lee and others

Table 2. Summary of pattern groups produced by RFLP analysis of $16 \mathrm{~S}$ rDNA from representative type strains of phytoplasmas

The numbers in each column represent the number of distinct RFLP types obtained with each restriction endonuclease.

\begin{tabular}{|c|c|c|c|c|c|c|c|c|c|c|c|c|c|c|c|c|c|c|}
\hline \multirow[t]{2}{*}{ Strain } & \multirow[t]{2}{*}{$16 \mathrm{Sr}$ group $\rangle^{\dagger}$} & \multicolumn{17}{|c|}{ No. RFLP types obtained with restriction enzyme: } \\
\hline & & Msel & $A l u \mathbf{I}$ & Rsal & Hhal & HaelII & HpalI & $T a q \mathrm{I}$ & Hinfl & Sau3AI & KpnI & Thal & BamHI & Dral & $E c o R I$ & Hpal & Sspl & $B f a \mathrm{I}$ \\
\hline BB & I-A & 1 & 1 & 1 & 1 & 1 & 1 & 1 & 1 & 1 & 1 & 1 & 1 & 1 & 1 & 1 & 1 & 1 \\
\hline AYI & $\mathrm{I}-\mathrm{B}$ & 1 & $i$ & 1 & 2 & 1 & 1 & $\mathrm{i}$ & 1 & 1 & 1 & 1 & $i$ & $i$ & i & $i$ & 1 & 2 \\
\hline MIAY & $\mathrm{I}-\mathrm{B}$ & 1 & 1 & 1 & 2 & 1 & 1 & 1 & 1 & 1 & 1 & 1 & 1 & 1 & 1 & 1 & 1 & 2 \\
\hline MBS & I-B & 1 & 1 & 1 & 2 & 1 & 1 & 1 & 1 & 1 & 1 & 1 & 1 & 1 & 1 & 1 & 1 & 2 \\
\hline MPY & I-B & 1 & 1 & 1 & 2 & 1 & 1 & 1 & $4 ?$ & 1 & 1 & 1 & 1 & 1 & 1 & 1 & 1 & 2 \\
\hline CPh & 1-C & 2 & 2 & 1 & 1 & 2 & 1 & 1 & 1 & 1 & 1 & 1 & 1 & 1 & I & 1 & 1 & 2 \\
\hline PaWB & I-D & 3 & 1 & 1 & 2 & 1 & 1 & 1 & 1 & 1 & 1 & 1 & 1 & 1 & 1 & 1 & 1 & 2 \\
\hline BBS1 & $\mathrm{I}-\mathrm{E}$ & 1 & 3 & 1 & 1 & 1 & 2 & 1 & 1 & 1 & 1 & 1 & 1 & 1 & 1 & 1 & 1 & 2 \\
\hline BBS3 & I-E & 1 & 1 & 1 & 1 & 1 & 2 & 1 & 1 & 1 & 1 & 1 & 1 & 1 & 1 & 1 & 1 & 2 \\
\hline (ACLR-AY) & $\mathrm{l}-\mathrm{F}$ & 4 & 1 & 7 & 1 & 1 & 1 & 1 & 1 & 1 & 2 & 1 & 1 & 1 & 1 & 1 & 1 & 2 \\
\hline PnWB & $11-A$ & 6 & 4 & 2 & 3 & 3 & 3 & 2 & 2 & 2 & 3 & 1 & 1 & 1 & 1 & 1 & 1 & 3 \\
\hline (WBDI.) & II-B & 7 & 4 & 2 & 3 & 3 & 4 & $i$ & 2 & 2 & 3 & $i$ & 1 & 1 & 1 & 1 & 1 & 3 \\
\hline (FBP) & II-C & 7 & 4 & 2 & 3 & 3 & 3 & 1 & 2 & 2 & 3 & 1 & 1 & 1 & 1 & 1 & 1 & 3 \\
\hline SPLL & II-D & 6 & 5 & 2 & & & 3 & & & & & & & & & & & \\
\hline $\mathrm{Cx}$ & III-A & 8 & 6 & 2 & 1 & 4 & 5 & 1 & 2 & 3 & 3 & 3 & 1 & 1 & 1 & 1 & 1 & 1 \\
\hline CYE & III-B & 9 & 6 & 2 & $i$ & 4 & 6 & 1 & 2 & 4 & 3 & 3 & 1 & 1 & 1 & 1 & 1 & $i$ \\
\hline PB & III-C & 10 & 6 & 2 & 4 & 4 & 6 & 1 & 2 & 4 & 3 & 4 & 1 & 1 & 1 & 1 & 1 & 4 \\
\hline GR1 & III-D & 11 & 6 & 2 & 4 & 4 & 6 & 1 & 2 & 4 & 3 & 5 & 1 & 1 & 1 & 1 & 1 & 1 \\
\hline SPI & III-E & 9 & 6 & 2 & 5 & 4 & 5 & 1 & 2 & 3 & 3 & 3 & 1 & 1 & 1 & 1 & 1 & 1 \\
\hline nW1 & $111-5$ & 9 & 6 & 2 & 4 & 4 & 6 & 1 & 2 & 4 & 3 & 4 & 1 & 1 & 1 & 1 & 1 & 1 \\
\hline WWB & III-G & 9 & 6 & 3 & 1 & 4 & 5 & 1 & 2 & 3 & 3 & 3 & 1 & 1 & 1 & 1 & 1 & 1 \\
\hline PoiBI & III-H & 9 & 6 & 2 & 1 & 4 & 5 & 1 & 2 & 3 & 3 & 3 & 1 & 1 & 1 & 1 & 1 & 4 \\
\hline LY3 & IV-A & 12 & 7 & 4 & 6 & 4 & 5 & 1 & 3 & 4 & 3 & 3 & 2 & 1 & 1 & 1 & 1 & 2 \\
\hline (LDY) & $I V-B$ & 13 & 8 & 4 & 6 & 4 & 5 & 1 & 3 & 4 & 3 & 3 & 2 & 1 & 1 & 1 & 1 & 2 \\
\hline (LDT) & IV-C & 14 & 7 & 4 & 4 & 2 & 5 & 1 & 3 & 4 & 3 & 3 & 2 & 1 & 1 & 1 & 1 & 2 \\
\hline EY1 & $\mathrm{V}-\mathrm{A}$ & 14 & 9 & 5 & 2 & 5 & 7 & 1 & 2 & 4 & 3 & 3 & 1 & 1 & 1 & 1 & 1 & 1 \\
\hline CLY & $\mathrm{V}-\mathrm{B}$ & 14 & 9 & 6 & 2 & 5 & 8 & i & 2 & 4 & 3 & 3 & 1 & 1 & 1 & 1 & 1 & 1 \\
\hline JWB & V-B & 14 & 9 & 6 & 2 & 5 & 8 & 1 & 2 & 4 & 3 & 3 & 1 & 1 & 1 & 1 & 1 & 1 \\
\hline RS & $\mathrm{V}-\mathrm{C}$ & 14 & 9 & 5 & 2 & 5 & 7 & 1 & 2 & 4 & 3 & 3 & 1 & 1 & 1 & 1 & 1 & 5 \\
\hline GVY & $\mathrm{V}-\mathrm{C}$ & 14 & 9 & 5 & 2 & 5 & 7 & 1 & 2 & 4 & 3 & 3 & i & 1 & 1 & 1 & 1 & 5 \\
\hline FD & V.C & 14 & 9 & 5 & 2 & 5 & 7 & 1 & 2 & 4 & 3 & 3 & 1 & 1 & 1 & 1 & 1 & 5 \\
\hline$C P$ & VI-A & 15 & 10 & 6 & 7 & 5 & 7 & 1 & 2 & 4 & 3 & 3 & 1 & 1 & 1 & 1 & 1 & 1 \\
\hline $\operatorname{Ash} Y$ & VII-A & 16 & 11 & 6 & 8 & 4 & 7 & 3 & 2 & 4 & 3 & 3 & 1 & 1 & 1 & 1 & 1 & 1 \\
\hline LfWB & VIII-A & 14 & 6 & 6 & 7 & 5 & 7 & 1 & 2 & 4 & 3 & 1 & 1 & 1 & 1 & 1 & 1 & 1 \\
\hline PPWB & IX-A & 17 & 12 & 4 & 9 & 6 & 7 & 4 & 4 & 4 & 3 & 1 & 1 & 2 & 1 & 1 & 1 & 1 \\
\hline AP-A & $\mathrm{X}-\mathrm{A}$ & 18 & 13 & 6 & 1 & 7 & 7 & 1 & 2 & 1 & 3 & 2 & 1 & 1 & 1 & 1 & 2 & 5 \\
\hline $\operatorname{ACLR}(I t a)$ & X-B & 19 & 13 & 4 & 1 & 7 & 7 & 5 & 2 & 1 & 3 & 2 & $i$ & $i$ & 1 & i & 1 & 5 \\
\hline PD & $\mathrm{X}-\mathrm{C}$ & 18 & 13 & 6 & 1 & 7 & 7 & 1 & 2 & i & 3 & 2 & 1 & 1 & 1 & 1 & 1 & 5 \\
\hline (SPAR) & $X-D$ & 20 & 13 & 6 & 1 & 7 & 7 & 1 & 2 & 1 & 3 & 4 & 1 & 1 & 1 & 1 & 1 & 6 \\
\hline (BAWB) & $X-E$ & 21 & 14 & 6 & 1 & 5 & 9 & 2 & 2 & 1 & 3 & 2 & 1 & 1 & 1 & 1 & 1 & $s$ \\
\hline RYD & $\mathrm{XI}-\mathrm{A}$ & 22 & 7 & 6 & 1 & 4 & 7 & 6 & 2 & 5 & 3 & 1 & 1 & 1 & 1 & 1 & 1 & 1 \\
\hline SCWL & XI-B & 23 & 7 & 6 & 1 & 4 & 7 & 1 & 2 & 5 & 3 & 1 & 1 & 1 & 1 & 1 & 1 & 1 \\
\hline (BVK) & $\mathrm{XI}-\mathrm{C}$ & 18 & 7 & 6 & 1 & 4 & 7 & 7 & 2 & 5 & 3 & 1 & 1 & 1 & 1 & 1 & 1 & 1 \\
\hline STOL & XII-A & 24 & 1 & 1 & 1 & 1 & 1 & 7 & 1 & 1 & 1 & 1 & 1 & 1 & 1 & 1 & 1 & 2 \\
\hline $\mathrm{Coly}$ & XII-A & 24 & 1 & 1 & 1 & 1 & 1 & 7 & 1 & 1 & 1 & 1 & 1 & 1 & 1 & 1 & 1 & 2 \\
\hline AUSGY & XII-B & 25 & 15 & 1 & 1 & 1 & 1 & 1 & 1 & 1 & 1 & 1 & 1 & 1 & 1 & 1 & 1 & 2 \\
\hline MPV & XIII-A & 26 & 16 & 7 & 2 & 2 & 1 & 8 & 5 & 6 & 2 & 1 & 1 & 1 & 1 & 1 & 1 & 5 \\
\hline BGWL & XIV-A & 27 & 7 & 6 & 1 & 5 & 7 & 6 & 2 & 5 & 3 & 3 & 1 & 1 & 1 & 1 & 1 & 5 \\
\hline
\end{tabular}

* See Table 1 for descriptions of phytoplasma strains. Strains in bold represent type species for sub-groups. RFLP patterns of strains in parentheses were based on putative restriction sites. Patterns of strains MIAY, CLY, STOL, SPLL and AUSGY were based on previously published $(28,41,82)$ and unpublished (I.-M. Lee) data.

$\dagger$ Letters $(\mathrm{A}-\mathrm{H})$ represent sub-groups. Sub-group assignments for strains BBS3 and MPY are tentative. 
(a)

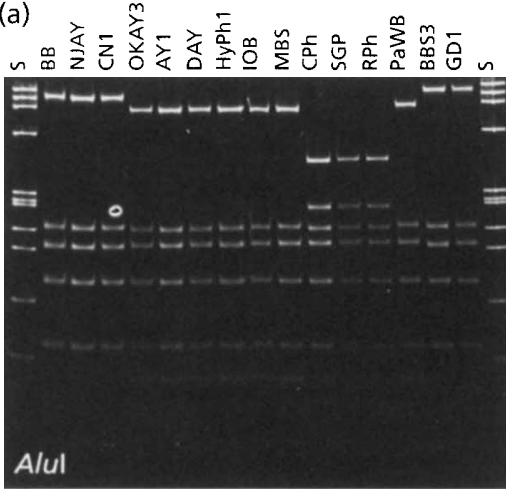

(b)

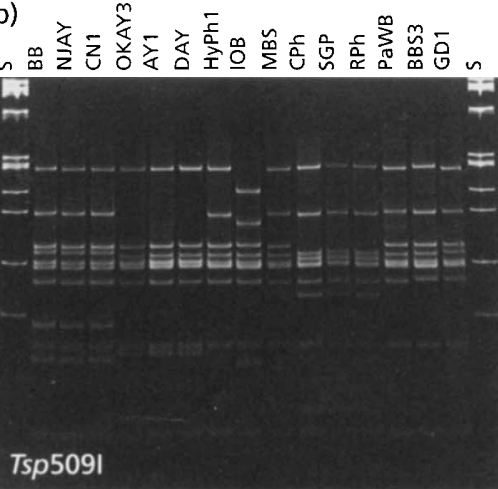

(c)

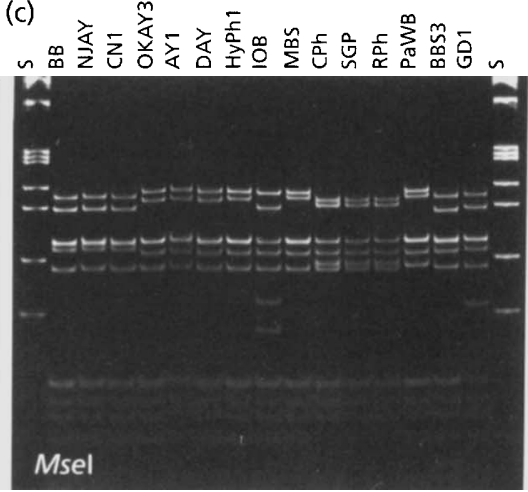

Fig. 2. RFLP analyses of ribosomal protein gene operon sequences amplified by PCR with primers $\mathrm{rpF} 1$ and $\mathrm{rpR} 1 \mathrm{from}$ representative phytoplasma strains belonging to aster yellows group (165rl). The PCR products were digested with restriction enzymes Alul (a), Tsp509l (b) or Msel (c). Lane S contained size markers as described in the legend to Fig. 1.

Table 3. Similarity coefficients derived from RFLP analysis of 16S rDNA of representative type strains of phytoplasmas

Each similarity coefficient is based on analyses of RFLP patterns generated by separate digestion of amplified 16S rDNA with 17 different restriction enzymes.

\begin{tabular}{|c|c|c|c|c|c|c|c|c|c|c|c|c|c|c|c|c|c|c|c|c|c|c|c|c|c|c|c|c|c|c|c|c|c|c|c|}
\hline & & 1 & 2 & 3 & 4 & 5 & 6 & 7 & 8 & 9 & 10 & 11 & 12 & 13 & 14 & 15 & 16 & 17 & 18 & 19 & 20 & 21 & 22 & 23 & 24 & 25 & 26 & 27 & 28 & 29 & 30 & 31 & 32 & 33 & 34 \\
\hline 1 & BB & 100 & & & & & & & & & & & & & & & & & & & & & & & & & & & & & & & & & \\
\hline 2 & AY 1 & 0.95 & $1 \cdot 00$ & & & & & & & & & & & & & & & & & & & & & & & & & & & & & & & & \\
\hline 3 & $\mathrm{CPh}$ & 093 & 0.93 & 1.00 & & & & & & & & & & & & & & & & & & & & & & & & & & & & & & & \\
\hline 4 & $\mathrm{PaWB}$ & $1: 94$ & 0.99 & 0.92 & $1 \cdot 00$ & & & & & & & & & & & & & & & & & & & & & & & & & & & & & & \\
\hline 5 & BBS1 & (f) 43 & 0.93 & 0.91 & 0.92 & $1 \cdot 00$ & & & & & & & & & & & & & & & & & & & & & & & & & & & & & \\
\hline 6 & CEL & 1187 & 0.90 & 0.88 & 0.89 & 0.88 & 1.00 & & & & & & & & & & & & & & & & & & & & & & & & & & & & \\
\hline 7 & MPV & 077 & 0.73 & 0.68 & 0.73 & 0.67 & 0.72 & 1.00 & & & & & & & & & & & & & & & & & & & & & & & & & & & \\
\hline 8 & MBS & 1195 & 1.00 & 0.93 & 0.99 & 0.92 & $0 \cdot 90$ & 0.73 & 1.00 & & & & & & & & & & & & & & & & & & & & & & & & & & \\
\hline 9 & BBS3 & 0.95 & 0.95 & 0.93 & 0.94 & 0.98 & 0.90 & 0.68 & 0.96 & $1 \cdot 00$ & & & & & & & & & & & & & & & & & & & & & & & & & \\
\hline 10 & MPY & 0.93 & 0.98 & 0.93 & 0.97 & 0.93 & 0.88 & 0.72 & 0.98 & 0.95 & $1 \cdot 00$ & & & & & & & & & & & & & & & & & & & & & & & & \\
\hline 11 & PnWB & 051 & 0.50 & 0.50 & 0.55 & 0.51 & 0.48 & 0.50 & 0.50 & 0.50 & 0.51 & 1.00 & & & & & & & & & & & & & & & & & & & & & & & \\
\hline 12 & $C X$ & 0.60 & 0.55 & 0.59 & 0.56 & 0.56 & 0.52 & 0.58 & 0.55 & 0.55 & 0.54 & 0.66 & $1 \cdot 00$ & & & & & & & & & & & & & & & & & & & & & & \\
\hline 13 & CYE & 0.60 & 0.56 & 0.59 & 0.57 & 0.60 & 0.53 & 0.60 & 0.56 & 0.59 & 0.55 & 0.67 & 0.93 & $1 \cdot 00$ & & & & & & & & & & & & & & & & & & & & & \\
\hline 14 & PB & 0.57 & 0.52 & 0.56 & 0.53 & 0.57 & 0.49 & 0.53 & 0.54 & 0.57 & 0.53 & 0.65 & 0.85 & 0.92 & $1 \cdot 00$ & & & & & & & & & & & & & & & & & & & & \\
\hline 15 & GRY & 0.57 & 0.53 & 0.56 & 0.52 & 0.57 & 0.52 & 0.52 & 0.50 & 0.54 & (0).49 & 0.64 & 0.86 & 0.92 & 0.94 & 1.00 & & & & & & & & & & & & & & & & & & & \\
\hline 16 & SPI & 0.54 & 0.55 & 0.58 & 0.56 & 0.56 & 0.52 & 0.56 & 0.53 & 0.53 & 0.52 & $(1.64$ & 0.97 & 0.92 & 0.90 & $0-89$ & $1 \cdot 00$ & & & & & & & & & & & & & & & & & & \\
\hline 17 & WWB & (1.60) & 0.55 & 0.59 & 0.56 & 0.56 & 0.52 & 0.58 & 0.55 & 0.55 & 0.54 & 0.64 & 0.98 & 0.94 & 0.88 & 0.87 & 0.95 & 1.00 & & & & & & & & & & & & & & & & & \\
\hline 18 & MWI & 6: 57 & 0.52 & 0.56 & 0.53 & 0.57 & 0.49 & 0.57 & 0.52 & 0.56 & 0.51 & 0.65 & 0.87 & 0.94 & 0.94 & 0.98 & 0.90 & 0.85 & $1 \cdot 00$ & & & & & & & & & & & & & & & & \\
\hline 19 & PoiBl & 060 & 0.56 & 0.59 & 0.57 & 0.57 & 0.53 & 0.57 & 0.56 & 0.56 & 0.55 & 0.65 & 0.99 & 0.94 & 0.88 & 0.90 & 0.98 & 0.97 & 0.88 & $1 \cdot 00$ & & & & & & & & & & & & & & & \\
\hline 20 & LY3 & $1: 62$ & 0.57 & 0.59 & 0.56 & 0.56 & 0.54 & 0.54 & 0.60 & $0 \cdot 60$ & 0.59 & 0.54 & 0.73 & 0.74 & 0.72 & 0.71 & 0.71 & 0.73 & 0.68 & 0.74 & $1 \cdot 00$ & & & & & & & & & & & & & & \\
\hline 21 & EYl & $05 ?$ & 0.54 & 0.52 & 0.54 & 0.53 & 0.51 & 0.53 & 0.54 & 0.52 & 0.53 & 0.52 & 0.65 & 0.66 & 0.64 & $0 \cdot 63$ & $0 \cdot 64$ & 0.65 & 0.64 & 0.68 & 0.67 & 100 & & & & & & & & & & & & & \\
\hline 22 & JWB & 051 & 0.50 & 0.49 & 0.50 & 0.51 & 0.48 & 0.50 & 0.50 & 0.50 & 0.50 & 0.56 & 0.65 & 0.68 & 0.66 & $0-65$ & $0 \cdot 64$ & 0.65 & 0.64 & 0.66 & 0.65 & 0.93 & $1 \cdot 00$ & & & & & & & & & & & & \\
\hline 23 & RS & 0.55 & 0.54 & 0.52 & 0.53 & 0.53 & 0.51 & 0.57 & 0.54 & 0.52 & 0.53 & $0 \cdot 51$ & 0.65 & 0.65 & 0.63 & $0 \cdot 62$ & $0 \cdot 64$ & 0.65 & 0.63 & 0.67 & 0.67 & 0.97 & 0.90 & 1.00 & & & & & & & & & & & \\
\hline 24 & GVY & 055 & 0.54 & 0.52 & 0.53 & 0.53 & 0.51 & 0.57 & 0. 54 & 0.52 & 0.53 & $0 \cdot 51$ & 0.65 & 0.65 & 0.63 & $0 \cdot 62$ & 0.64 & 0.65 & 0.63 & $0 \cdot 67$ & 0.67 & 0.97 & $0-90$ & $1 \cdot 00$ & $1 \cdot 00$ & & & & & & & & & & \\
\hline 25 & CP & 0.57 & 0.54 & 0.54 & 0.54 & 0.55 & 0.51 & 0.51 & (0).54 & 0.54 & 0.53 & 0.55 & 0.73 & 0.74 & 0.72 & 0.71 & 0.73 & 0.73 & 0.70 & 0.74 & 0.73 & 0.89 & 0.89 & 0.86 & 0.86 & 1.00 & & & & & & & & & \\
\hline 26 & $A \sin Y$ & 0.56 & 0.59 & 0.53 & 0.58 & 0.52 & 0.54 & 0.54 & 0.59 & 0.53 & 0.58 & 0.56 & 0.69 & 0.72 & 0.66 & $0 \cdot 65$ & 0.70 & 0.67 & 0.64 & 0.68 & 0.69 & 0.83 & 0.83 & 0.80 & 0.80 & $0 \cdot 90$ & $1 \cdot 00$ & & & & & & & & \\
\hline 27 & LrWB & 060 & 0.57 & 0.59 & 0.56 & 0.58 & 0.53 & 0.52 & 0.57 & 0.57 & 0.56 & 0.58 & 0.70 & 0.71 & 0.71 & 0.69 & 0.69 & 0.70 & 0.69 & 0.71 & 0.69 & 0.79 & 0.79 & 0.70 & 0.76 & 0.88 & 0.74 & $1 \cdot 00$ & & & & & & & \\
\hline 28 & PPWB & 1.52 & 0.51 & 0.50 & 0.51 & 0.52 & 0.50 & 0.49 & 0.51 & $0 \cdot 51$ & $0 \cdot 50$ & $0 \cdot 60$ & 0.58 & 0.64 & 0.64 & $0 \cdot 65$ & 0.57 & 0.58 & 0.56 & 0.58 & 0.57 & 0.65 & 0.63 & 0.63 & $0 \cdot 63$ & 0.69 & 0.65 & $0 \cdot 70$ & 1.00 & & & & & & \\
\hline 29 & AP & $0.5 x$ & 0.55 & 0.57 & 0.55 & 0.54 & 0.54 & 0.54 & 0.55 & 0.55 & 0. 54 & 0.45 & 0.60 & $0 \cdot 60$ & 0.59 & $0 \cdot 57$ & 0.57 & $0 \cdot 60$ & 0.60 & 0.58 & 0.58 & 0.57 & 0.57 & 0.61 & 0.61 & 0.64 & 0.58 & 0.62 & 0.54 & $1 \cdot 00$ & & & & & \\
\hline 30 & ACLR(Ita) & 062 & 0.58 & 0.60 & 0.58 & 0.58 & 0.59 & 0.63 & 0.58 & 0.58 & 0.67 & 0.49 & $0 \cdot 61$ & $0 \cdot 62$ & $0 \cdot 60$ & 0.55 & 0.59 & 0.61 & 0.60 & $0 \cdot 62$ & 0.59 & 0.59 & 0.57 & 0.63 & 0.63 & $0 \cdot 63$ & 0.59 & 0.62 & 0.55 & 0.93 & $1 \cdot 00$ & & & & \\
\hline 31 & PD & 0.61 & 0.62 & 0.56 & 0.61 & 0.57 & 0.57 & 0.65 & 0.58 & 0.58 & 0.57 & 0.48 & 0.60 & 0.63 & 0.61 & 0.56 & $0 \cdot 60$ & 0.63 & 0.61 & 0.63 & 0.60 & 0.60 & 0.60 & 0.64 & 0.64 & $0 \cdot 67$ & 0.61 & 0.65 & 0.55 & 0.97 & 0.94 & 1.00 & & & \\
\hline 32 & RYD & (1.63 & 0.58 & 0.55 & $0 \cdot 60$ & 0.58 & 0.57 & 0.56 & 0.58 & 0.58 & 0.59 & 0.66 & 0.71 & 0.74 & 0.72 & 0.69 & 0.71 & 0.73 & 0.71 & 0.75 & 0.71 & 0.67 & 0.67 & 0.65 & 0.65 & 0.76 & 0.77 & 0.74 & 0.65 & 0.64 & 0.65 & 0.67 & 1.00 & & \\
\hline 33 & SCWL & 1265 & 0.60 & 0.57 & 0.62 & 0.60 & 0.57 & 0.58 & 0.60 & 0.60 & 0.59 & 0.68 & 0.75 & 0.78 & 0.74 & 0.73 & 0.75 & 0.77 & 0.75 & 0.79 & 0.78 & 0.68 & 0.69 & 0.67 & 0.67 & 0.78 & 0.75 & 0.77 & 0.63 & 0.66 & $0 \cdot 65$ & 0.69 & 0.94 & $1 \cdot 00$ & \\
\hline 34 & BGWL & $05 x$ & 0.55 & 0.55 & 0.56 & 0.54 & 0.54 & 0.58 & 0.57 & 0.57 & 0.56 & 0.56 & 0.69 & 0.72 & 0.66 & 0.67 & 0.69 & 0.71 & 0.67 & 0.73 & 0.71 & 0.69 & $0 \cdot 71$ & 0.74 & 0.74 & 0.80 & 0.73 & 0.72 & 0.63 & 0.70 & 0.71 & 0.73 & 0.88 & $0 \cdot 84$ & 1.00 \\
\hline
\end{tabular}

practice, several of the most useful restriction enzymes, such as MseI, AluI, RsaI, HhaI, HpaII and TaqI, should be included for preliminary classification of phytoplasmas.

\section{Delineation of phytoplasma groups and sub-groups}

The comprehensive classification scheme combined with parallel phylogenetic analyses has formed a basis 


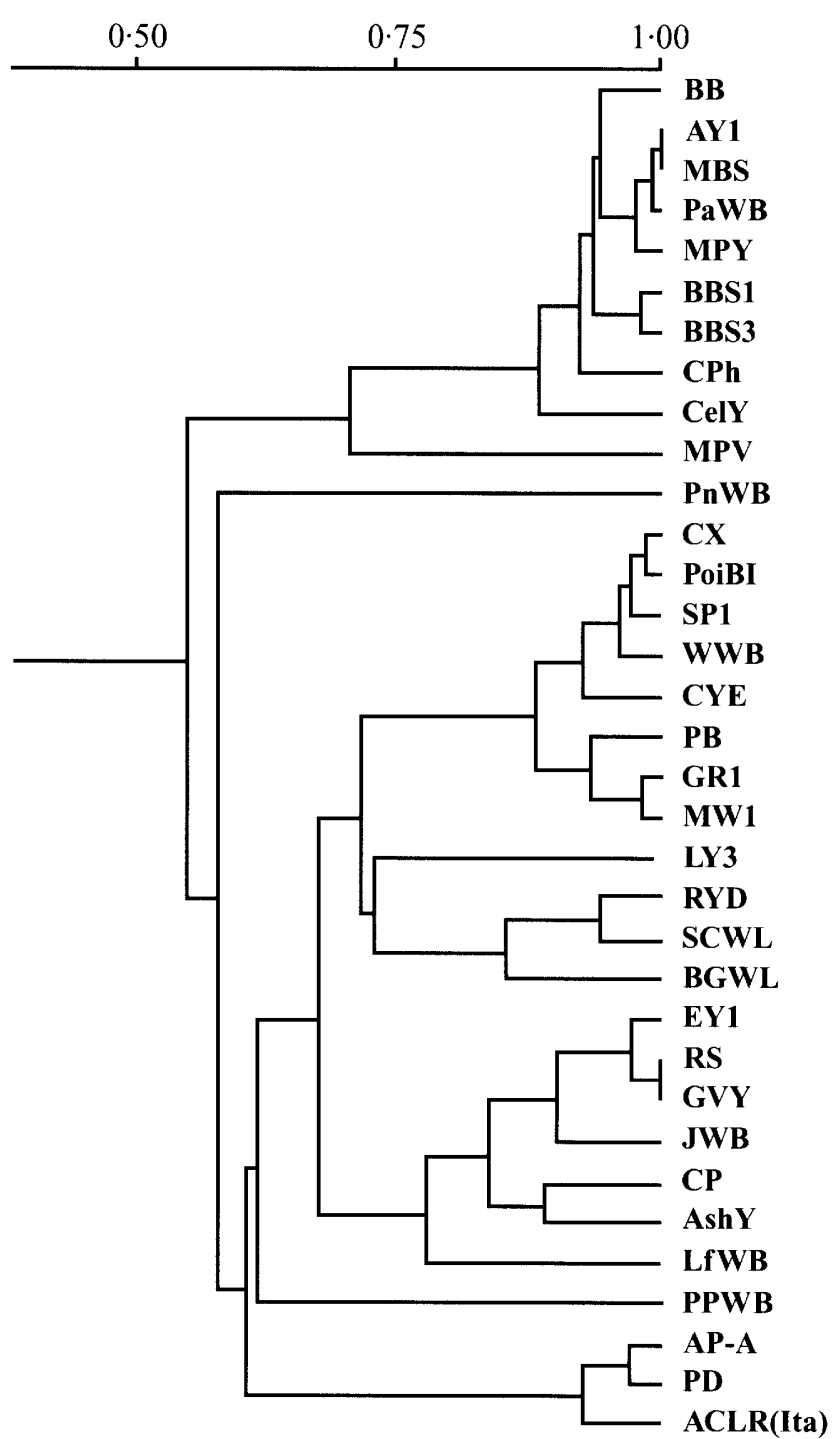

Fig. 3. Dendrogram obtained by cluster analysis of similarity coefficients derived from RFLP analysis of 16S rDNA of the 34 representative phytoplasmas. The scale refers to the similarity index. Phytoplasma strain descriptions are as in Table 1.

for establishing a formal phytoplasma taxonomy. Each $16 \mathrm{Sr}$ group, which corresponded to a subclade, based on cladistic phylogenetic analysis of $16 \mathrm{~S}$ rRNA gene sequences was proposed to represent at least one species (49). At the 10th International Congress of the International Organization for Mycoplasmology, the trivial name 'phytoplasma' was officially adopted as the Candidatus genus name to replace 'mycoplasmalike organism' and it has been proposed that within the putative genus phytoplasma, each phylogenetic subclade represents a Candidatus species. Thus far, two phytoplasma Candidatus species, 'Candidatus Phytoplasma aurantifolia' (associated with the witches'broom disease of lime) (145) and 'Candidatus Phytoplasma australiense' (associated with Australian grapevine yellows) (28) have been proposed.

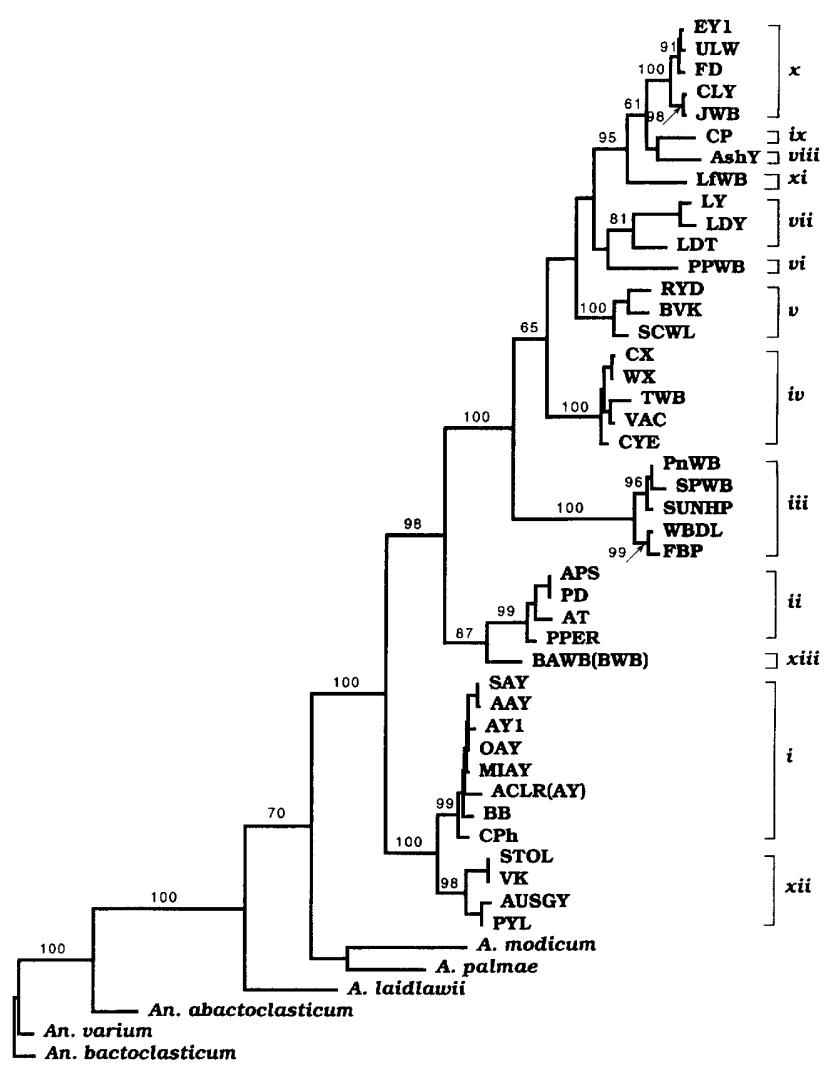

Fig. 4. Phylogenetic tree constructed by parsimony analysis of full 16S rRNA sequences from 42 phytoplasmas, three Acholeplasma (A.) spp. and three Anaeroplasma (An.) spp., employing Anaeroplasma abactoclasticum as the outgroup. Branch lengths are proportional to the number of inferred character state transformations. Phylogenetic subclades identified are shown on the right. Bootstrap values (measures of support for the inferred subclades) are shown on branches. AAY, American aster yellow collected from Florida by R. E. McCoy. APS, Apple proliferation phytoplasma was collected from Spain (121). Other abbreviations are defined in Table 1.

The sub-groups within a given $16 \mathrm{Sr}$ group were differentiated based on restriction sites. A new subgroup was assigned if the phytoplasma strain had one or more restriction sites different from those in all the existing members of the given group. While two $16 \mathrm{~S}$ rRNA gene operons have been reported in phytoplasma $(83,87,88,117)$, in some cases (this work and R. Jomantiene \& R. E. Davis, unpublished) differences between phytoplasmas have been detected in only one of the two 16S rRNA genes (e.g. strains $\mathrm{CPh}$, WWB and SP1; see Fig. 1b-d). Sub-group designations for strains WWB and SP1 were based on combined patterns from both operons and will be considered to be only tentative until more substantial evidence indicates that the two operons in these strains are different. Most of the sub-groups identified were consistent with genomic subclusters previously determined based on dot- and Southern-hybridization assays of total genomic DNA $(45,78,81)$. However, some previously identified subclusters based on partial DNA homology were not readily differentiated by 
RFLP analysis of the highly conserved 16S rRNA gene sequence (81). Therefore, combined RFLP analyses of $16 \mathrm{~S} \mathrm{rRNA}$ and/or ribosomal protein operon gene sequences (50) were applied for a finer sub-group differentiation. In general, sub-group delineation based on RFLP analysis of the 16S rRNA gene was consistent with that based on ribosomal protein gene sequence. Some members within a given $16 \mathrm{Sr}$ subgroup can be further differentiated, based on ribosomal protein gene sequences. For example, among members of $16 \mathrm{SrI}-\mathrm{B}$, phytoplasma strains $\mathrm{HyPH} 1$, IOB and MBS represent additional sub-groups based on combined RFLP analyses of $16 \mathrm{~S}$ rRNA and ribosomal protein gene sequences (Fig. 2) where ribosomal protein RFLP patterns are identified by comparison only to the members of the $16 \mathrm{Sr}$ subgroup. Several members of $16 \mathrm{Sr}$ sub-groups III-A, B and $\mathrm{V}$-A also represented additional sub-groups based on analyses of 16S rRNA and ribosomal protein gene sequences (Table 1). Other less-conserved gene sequences (e.g. 23S-16S rRNA intergenic spacer region) or monoclonal antibodies can also be useful for finer sub-group differentiation $(63,66,98)$.

While there was consensus in designation of a temporary taxonomic unit, 'Candidatus Phytoplasma' species, for each of the major phytoplasma groups (phylogenetic subclades or corresponding $16 \mathrm{Sr}$ groups), no consensus has been reached for assigning an appropriate taxonomic rank to each of the subgroups recognized. It is evident that the majority of the designated sub-groups within a given $16 \mathrm{Sr}$ group represent distinct phytoplasma subclusters, which have unique ecological niches in nature. For example, apple proliferation phytoplasma (sub-group $16 \mathrm{Sr} \mathrm{X}-\mathrm{A}$ ), pear decline phytoplasma (sub-group $16 \mathrm{SrX}-\mathrm{C}$ ), and plum leptonecrosis and European stone fruit phytoplasmas (sub-group 16 $\mathrm{SrX}-\mathrm{B}$ ) were associated with their preferential hosts (plants and/or insect vectors) in nature; mutual cross-infections among various hosts by these phytoplasmas have not been reported. Likewise, paulownia witches'-broom phytoplasma (sub-group 16SrI-D). blueberry stunt phytoplasma (sub-group 16SrI-E), maize bushy stunt phytoplasma [sub-group 16SrI-B(rp-L)], pecan bunch phytoplasma (sub-group 16SrIII-C), spiraea stunt phytoplasma (sub-group 16SrIII-E), walnut witches'-broom phytoplasma (subgroup $16 \mathrm{SrIII}-\mathrm{G}$ ), cherry lethal yellows phytoplasma [sub-group 16SrV-B(rp-B)] and jujube witches'-broom phytoplasma [sub-group 16SrV-B(rp-C)] all have their own ecological niches (specific or relatively narrow host range). Many sub-groups are geographically isolated. For example, sub-group 16SrI-A phytoplasmas have only been reported in North America. Sub-group 16 SrI-D phytoplasma is present only in eastern Asia (143). A taxonomic rank of at least subspecies level was previously proposed for affiliating each sub-group that was defined on the basis of RFLP analysis of 16S rRNA and/or ribosomal protein gene sequences (50). It is necessary and practical to identify the range of genomic heterogeneity among members of each proposed Candidatus species. However, for some sub-groups, for example III-A(rp-A) and III-A(rp-B), which share similar ecological niches, assignment of differential taxonomic ranks may require additional genomic information.

\section{Rationale for proposed taxonomic ranks of RFLP groups and sub-groups}

The extensive knowledge accumulated in the last decade on the molecular biology and phylogeny of bacteria has changed the traditional concept of Mollicutes taxonomy $(4,5,10,38,58,102,111,129$, 136-141). Polyphasic taxonomy, which aims to integrate different kinds of information (phenotypic, genotypic and phylogenetic) on micro-organisms in their classification, has become a consensus approach to modern bacterial systematics $(38,58,131)$. It is generally accepted that bacterial classification should reflect the phylogenetic relationship, deduced by analysis of $16 \mathrm{~S}$ or $23 \mathrm{~S}$ rRNA sequences. Because of the deficiencies in the traditional phenotypically oriented system, the International Committee on Systematic Bacteriology (ICSB) Subcommittee on the taxonomy of Mollicutes has agreed to, and adopted the policy of, basing bacterial taxonomy on phylogeny $(38,58)$. For uncultured phytoplasmas, basing taxonomy on phylogeny is inevitable because the phenotypic criteria are not attainable. A decision was also made that the complete sequence of the bacterial genome would be the basis for assignment of the basic taxonomic unit, the species. According to the ICSB's recommended criteria, the phylogenetic definition of a species would include strains with at least $70 \%$ DNA homology, while a subspecies would include strains with $70-85 \%$ DNA homology. For uncultured phytoplasmas, species differentiation based on DNA-DNA homology has not been attempted because pure phytoplasma DNA is difficult to obtain. However, based on their review of data in the literature, Stackebrandt \& Goebel (129) recently noted that organisms sharing less than $97 \%$ 16S rRNA sequence homology will not give a DNA reassociation of more than $60 \%$ regardless of which DNA-DNA hybridization methods are used. This indicates the potential of replacing DNA-DNA hybridization with $16 \mathrm{~S}$ rRNA sequence homology in the description of new species, provided that rRNA sequences are available and the sequences are accurately determined.

16S rRNA sequence homologies are $88-94 \%$ between two distinct phytoplasma 16S rRNA groups, and 95-98\% between two sub-groups within a given group (49, and this study). Based on the criteria proposed by Stackebrandt \& Goebel (129), each phytoplasma 16S rRNA group and some $16 \mathrm{Sr}$ sub-group phytoplasma strains can be assigned as a taxon at the species level. Because of the highly conserved nature of $16 \mathrm{~S}$ rRNA gene sequences, there is no defined threshhold of sequence homology for assigning a species. Therefore, the taxonomic rank of the phytoplasma sub-groups 
which share $97 \%$ or more $16 \mathrm{~S}$ rRNA sequence homologies are uncertain. For example, in a comparative study of the relationship between 16S rRNA sequence homology and DNA-DNA homologies among species in the genus Bacillus, Fox et al. (38) noted that although $16 \mathrm{~S}$ rRNA sequence identity can be used effectively to establish relationships between genera and well-resolved species, $16 \mathrm{~S}$ rRNA sequence identity alone may not be sufficient to guarantee species identity. Two Bacillus species with $23-50 \%$ DNA-DNA homology shared 99.8\% 16S rRNA sequence similarity. In contrast, they did not find any instances of strains that were well resolved by $16 \mathrm{~S}$ rRNA sequence analysis which could not also be differentiated on the basis of DNA-DNA hybridization.

The inability to obtain pure cultures of phytoplasmas makes conventional DNA-DNA homology studies difficult. DNA-DNA homology data do not exist to verify the taxonomic ranks assigned to each phytoplasma $16 \mathrm{Sr}$ group or sub-group in this study. Our approach, using $16 \mathrm{~S}$ rRNA gene sequence to differentiate major phytoplasma groups and using the 16S rRNA gene supplemented with less conserved sequences (e.g. ribosomal protein gene clusters) to differentiate sub-groups within each group, should give a classification of phytoplasma strains that reflects the true genomic variation. Based on partial DNA homology data gathered in the last decade, the proposed designation of 'Candidatus Phytoplasma' species or subspecies on the basis of phylogenetic relatedness determined by RFLP analyses of $16 \mathrm{~S}$ rRNA (and ribosomal protein) gene sequences seems appropriate. The sub-groups identified by combined RFLP analyses of these conserved gene sequences were consistent with the subclusters identified by relative DNA homology studies of total genomic DNA with a number of cloned phytoplasma DNA probes $(45,50,78,81)$. Hence, small variations in conserved 16S rRNA or ribosomal protein genes, or in $16 \mathrm{~S}-23 \mathrm{~S}$ intergenic spacer region sequences were phylogenetically significant, since they represent much greater variations in total genomic DNA sequences. This notion was verified in other culturable prokaryotic systems (73), in which the dissimilarities of $16 \mathrm{~S}$ rRNA gene sequences ranged from $2-10 \%$ among established species and 1-3\% among subspecies, and the difference in DNA homology between species or subspecies fell within the ranges proposed by the ICSB. While a temporary nomenclature of ' Candidatus Phytoplasma' species has been accepted by ICSB for assigning each 16SrRNA group (equivalent to a phylogenetic subclade), we propose that a new convention be adopted to refer to the distinct sub-groups encompassed by a Candidatus species. For example, maize bushy stunt phytoplasma [16SrI-B(rp-L)] represents one of the several sub-groups identified within aster yellows group 16SrI. The maize bushy stunt sub-group would be referred to as 'Candidatus Phytoplasma asteri' [16SrI-B(rp-L)] to distinguish from other sub-groups in the aster yellows group $(16 \mathrm{SrI})$.

\section{Concluding remarks}

Biological properties such as symptomatology, range of susceptible plant hosts and relationships to insect vectors had been the major criteria for diagnosing the phytoplasmal diseases and the associated phytoplasmal strains before molecular-based methods became available $(18,35,39,77,101,123,124,132)$. In practice, they remain important tools for preliminary identification of putative phytoplasmal diseases. The identities of the putative causal agents can now be accurately identified and defined on the basis of phylogenetic criteria. It is clear that a given disease of the same plant host based on similar symptomatology can be associated with two or more distinct phytoplasmas in different geographical regions, and that a given type of phytoplasma (e.g. 16SrI-B) can potentially inflict various diseases in different plant hosts. The traditional one disease-one phytoplasma concept is changing. Although, in many cases, characteristic biological properties are found to be linked with each of the putative taxonomic units (phytoplasma $16 \mathrm{Sr}$ groups or sub-groups) based on phylogenetic criteria, these biological properties can only be used as secondary criteria to define a given presumed causal agent (listed in Table 1).

\section{ACKNOWLEDGEMENTS}

We thank all of the individuals who provided phytoplasma strains used in this study and Lisa Lukaesko for excellent technical assistance.

\section{REFERENCES}

1. Ahrens, U., Lorenz, K. H. \& Seemüller, E. (1993). Genetic diversity among mycoplasmalike organisms associated with stone fruit diseases. Mol Plant-Microbe Interact 6, 686-691.

2. Ahrens, U. \& Seemüller, E. (1992). Detection of DNA of plant pathogenic mycoplasmalike organisms by a polymerase chain reaction that amplifies a sequence of the $16 \mathrm{~S}$ rRNA gene. Phytopathology 82, 828-832.

3. Alma, A., Davis, R. E., Vibio, M., Danielli, A., Bosco, D., Arzone, A. \& Bertaccini, A. (1996). Mixed infection of grapevines in northern Italy by phytoplasmas including $16 \mathrm{~S}$ rRNA RFLP sub-group 16Srl-B strains previously unreported in this host. Plant Dis 80, 418-421.

4. Amann, R. I., Ludwig, W. \& Schleifer, H. (1995). Phylogenetic identification and in situ detection of individual microbial cells without cultivation. Microbiol Rev 59, 143-169.

5. Ash, C., Farraw, A. E., Dorsch, M., Stackebrandt, E. \& Collins, M. D. (1991). Comparative analysis of Bacillus anthracis, Bacillus cereus, and related species on the basis of reverse transcriptase sequencing of 16S rRNA. Int $J$ Syst Bacteriol 41, 343-346.

6. Bertaccini, A., Davis, R. E., Lee, I.-M., Conti, M., Dally, E. L. \& Douglas, S. M. (1990). Detection of chrysanthemum yellows mycoplasmalike organism by dot hybridization and Southern blot analysis. Plant Dis 74, 40-43. 
7. Bertaccini, A., Vibio, M., Davis, R. E. \& Lee, I.-M. (1993) Molecular characterization of some mycoplasmalike organisms infecting plants in Italy. Petria $G$ Patol Plante 3. 9.

8. Bertaccini, A., Vibio, M. \& Stefani, E. (1995). Detection and molecular characterization of phytoplasmas infecting grapevine in Liguria (Italy). Phytopathol Mediterr 34, 137-141.

9. Bianco, P. A., Davis, R. E., Prince, J. P., Lee, I.-M., Gundersen, D. E., Fortusini, A. \& Belli, G. (1993). Double and single infections by aster yellows and elm yellows MLOs in grapevines with symptoms characteristic of flavescence doree. Riv Patol Veg SV 3, 69-82.

10. Boddinghaus, B., Wolters, J., Heikens, W. \& Bottger, E. C. (1990). Phylogenetic analysis and identification of different serovars of Mycobacterium intracellulare at the molecular level. FEMS Microbiol Lett 70, 197-204.

11. Bonnet, F., Saillard, C., Kollar, A., Seemüller, E., Dosba, F. \& Bové, J. M. (1990). Molecular probes for the apple proliferation MLO. Zentbl Bakteriol Suppl 20, 908-909.

12. Chen, J. C., Chang, C. J., Jarret, R. \& Gawel, N. (1992). Isolation and cloning of DNA fragments from mycoplasmalike organism associated with walnut witches'broom disease. Phytopathology 82, 306-309.

13. Chen, T.-A., Lei, J. D. \& Lin, C. P. (1992). Detection and identification of plant and insect mollicutes. In The Mycoplasmas, vol. 5, pp. 393-424. Edited by R. F. Whitcomb \& J. G. Tully. New York: Academic Press.

14. Chen, K. H., Credi, R. C., Loi, N., Maixner, M. \& Chen, T.-A. (1994). Identification and grouping of mycoplasmalike organisms associated with grapevine yellows and clover phyllody diseases based on immunological and molecular analyses. Appl Environ Microbiol 60, 1905-1913.

15. Chiykowski, L. N. (1962). Scaphytopious acutus (Say), a newly dicovered vector of celery-infecting aster-yellows virus. Can $J$ Bot 40, 799-801.

16. Chiykowski, L. N. (1991). Vector-pathogen-host plant relationships of clover phyllody mycoplasmalike organism and the vector leafhopper Paraphlepsius irroratus. Can J Plant Pathol 13, 11-18.

17. Chiykowski, L. N. \& Sinha, R. C. (1982). Herbaceous host plants of peach eastern X-disease agent. Can J Plant Pathol $4,8-15$

18. Chiykowski, L. N. \& Sinha, R. C. (1989). Differentiation of MLO disease by means of symptomatology and vector transmission. Zentbl Bakteriol Hyg Suppl 20, 280-287.

19. Clark, M. F., Morton, A. \& Buss, S. L. (1989). Preparation of MLO immunogens from plants and a comparison of polyclonal and monoclonal antibodies made against primula yellows MLO-associated antigens. Ann Appl Biol 114, $111-124$.

20. Daire, X., Boudon-Padieu, E., Berville, A., Schneider, B. \& Caudwell, A. (1992). Cloned DNA probes for detection of grapevine flavescence dorée mycoplasma-like organism (MLO). Ann Appl Biol 121, 95-103.

21. Daire, X., Clair, D., Larrue, J., Boudon-Padieu, E. \& Caudwell, A. (1993). Diversity among mycoplasma-like organisms inducing grapevine yellows in France. Vitis 32, 159-163.

22. Daire, X., Clair, D., Larrue, J. \& 11 other authors (1993). Occurrence of diverse MLOs in tissues of grapevine affected by grapevine yellows in different countries. Vitis $\mathbf{3 2}$, $247-248$.
23. Dale, J. L. \& Smith, L. D. (1975). Mycoplasmalike bodies observed in tomato plants with big bud in Arkansas. Plant Dis Rep 59, 455-458.

24. Davies, D. L., Barbara, D. J. \& Clark, M. F. (1995). The detection of MLOs associated with pear decline in pear trees and pear psyllids by polymerase chain rection. Acta Hortic 386, 484-488.

25. Davies, D. L. \& Clark, M. F. (1992). Production and characterization of polyclonal and monoclonal antibodies against peach yellow leafroll MLO-associated antigens. Acta Hortic 383, 275-283.

26. Davis, M. J., Tsai, J. H., Cox, R. L., McDaniel, L. L. \& Harrison, N. A. (1988). Cloning of chromosomal and extrachromosomal DNA of the mycoplasma-like organism that causes maize bushy stunt disease. Mol Plant-Microbe Interact 1, 295-302.

27. Davis, R. E., Dally, E. L., Bertaccini, A. \& 7 other authors (1993). Restriction fragment length polymorphism analyses and dot hybridization distiguish mycoplasmalike organisms associated with flavescence dorée and southern European grapevine yellows disease in Italy. Phytopathology 83, 772-776.

28. Davis, R. E., Dally, E. L., Gundersen, D. E., Lee, I.-M. \& Habili, N. (1997). 'Candidatus Phytoplasma australiense', a new phytoplasma taxon associated with Australian grapevine yellows. Int J Syst Bacteriol 47, 262-269.

29. Davis, R. E. \& Lee, I.-M. (1993). Cluster-specific polymerase chain reaction amplification of $16 \mathrm{~S}$ rDNA sequences for detection and identification of mycoplasmalike organisms. Phytopathology 83, 1008-1011.

30. Davis, R. E., Lee, I.-M., Douglas, S. M. \& Dally, E. L. (1990). Molecular cloning and detection of chromosomal and extrachromosomal DNA of the mycoplasmalike organism (MLO) associated with little leaf disease in periwinkle (Catharanthus roseus). Phytopathology 80, 789-793.

31. Davis, R. E., Prince, J. P., Hammond, R. W., Dally, E. L. \& Lee, I.-M. (1992). Polymerase chain reaction detection of Italian periwinkle virescence mycoplasmalike organism (MLO) and investigation of genetic relatedness with other MLOs. Phytopathol Mediterr 31, 5-12.

32. Davis, R. E., Sinclair, W. A., Lee, I.-M. \& Dally, E. L. (1991). Cloned DNA probes specific for detection of a mycoplasmalike organism associated with ash yellows. Mol Plant-Microbe Interact 5, 163-169.

33. Deng, S. \& Hiruki, C. (1991). Amplification of $16 \mathrm{~S}$ rRNA genes from culturable and non-culturable mollicutes. $J$ Microbiol Methods 14, 53-61.

34. Deng, S. \& Hiruki, C. (1991). Genetic relatedness between two non-culturable mycoplasmalike organisms revealed by nucleic acid hybridization and polymerase chain reaction. Phytopathology 81, 1475-1479.

35. Errampalli, D., Fletcher, J. \& Claypool, P. L. (1991). Incidence of yellows in carrot and lettuce, and characterization of mycoplasmalike organism isolates in Oklahoma. Plant Dis $75,579-584$.

36. Firrao, G. (1996). Molecular characterization of a phytoplasma causing phyllody in clover and other herbaceous hosts in northern Italy. Eur J Plant Pathol 102, 817-822.

37. Firrao, G., Gobbi, E. \& Locci, R. (1993). Use of polymerase chain reaction to produce oligonucleotide probes for mycoplasmalike organisms. Phytopathology 83, 602-607.

38. Fox, G. E., Wisotzkey, J. D. \& Jurtshuk, P. (1992). How close 
is close: $16 \mathrm{~S}$ rRNA sequence identity may not be sufficient to guarantee species identity. Int $J$ Syst Bacteriol 42, $166-170$.

39. Freitag, J. H. (1964). Interaction and mutual suppression among three strains of aster yellows virus. Virology 24, $401-413$.

40. Gibb, K. S. (1996). Phytoplasmas associated with papaya diseases in Australia. Plant Dis 80, 174-178.

41. Gibb, K. S., Padovan, A. C. \& Mogen, B. D. (1995). Studies on sweet potato little-leaf phytoplasma detected in sweet potato and other plant species in northern Australia. Phytopathology 85, 169-174.

42. Giunchedi, L., Pollini, C. P., Bissani, S., Vicchi, V. \& Babini, A. R. (1994). PCR detection of MLOs in quick decline-affected pear trees in Italy. Ann Appl Biol 124, 399403.

43. Golino, D. A., Oldfield, G. N. \& Gumpf, D. J. (1989). Experimental hosts of the beet leafhopper transmitted virescence agent. Plant Dis 73, 850-854.

44. Goodwin, P. H., Xue, B. G., Kuske, C. R. \& Sears, M. K. (1994). Amplification of plasmid DNA to detect plant pathogenic mycoplasmalike organisms. Ann Appl Biol 124, 27-36.

45. Griffiths, H. M., Gundersen, D. E., Sinclair, W. A., Lee, I.-M. \& Davis, R. E. (1994). Mycoplasmalike organisms from milkweed, goldenrod, and spiraca represent two new $16 \mathrm{~S}$ rRNA sub-groups and three new strain subclusters related to peach X-disease. Can J Plant Pathol 16, 255--266.

46. Griffiths, H. M., Sinclair, W. A., Davis, R. E., Lee, I.-M., Dally, E. L., Guo, H., Chen, T.-A. \& Hibben, C. R. (1994). Characterization of mycoplasmalike organisms from Fraxinus, Syringa, and associated plants from geographically diverse sites. Phytopathology 84, 119-126.

47. Gundersen, D. E. \& Lee, I.-M. (1996). Ultrasensitive detection of phytoplasmas by nested-PCR assays using two universal primer pairs. Phytopathol Mediterr 35, 144-151.

48. Gundersen, D. E., Lee, I.-M., Chang, C. J. \& Davis, R. E. (1994). RFLP analyses of ribosomal protein genes reveal strain diversity in MLO 16S rRNA groups I and III. Phytopathology 84, 1128.

49. Gundersen, D. E., Lee, I.-M., Rehner, S. A., Davis, R. E. \& Kingsbury, D. T. (1994). Phylogeny of mycoplasmalike organisms (phytoplasmas): a basis for their classification. $J$ Bacteriol 176, 5244-5254.

50. Gundersen, D. E., Lee, I.-M., Schaff, D. A., Harrison, N. A., Chang, C. J., Davis, R. E. \& Kingsbury, D. T. (1996). Genomic diversity and differentiation among phytoplasma strains in 16S rRNA group I (aster yellows and related phytoplasmas) and III (X-disease and related phytoplasmas). Int $J S_{y s t}$ Bacteriol 46, 64-75.

51. Guo, Y. H., Walla, J. A., Cheng, M. \& Lee, I.-M. (1996). Xdisease confirmation and distribution in chokecherry in North Dakota. Plant Dis 80, 95-102.

52. Harrison, N. A. (1996). PCR assay for detection of the phytoplasma associated with maize bushy stunt disease. Plant Dis 80, 263-269.

53. Harrison, N. A., Bourne, C. M., Cox, R. L., Tsai, J. H. \& Richardson, P. A. (1992). DNA probes for detection of mycoplasmalike organisms associated with lethal yellowing disease of palms in Florida. Phytopathology 82, 216-224.

54. Harrison, N. A. \& Richardson, P. A. (1994). Comparative investigation of MLOs associated with Caribbean and African coconut lethal decline diseases by DNA hybridization and PCR assays. Plant Dis 78, 507-511.
55. Harrison, N. A., Richardson, P. A., Kramer, J. B. \& Tsai, J. H. (1994). Detection of the mycoplasmalike organism associated with lethal yellowing disease of palms in Florida by polymerase chain reaction. Plant Pathol 43, 998-1008.

56. Harrison, N. A., Tsai, J. H., Bourne, C. M. \& Richardson, P. A. (1991). Molecular cloning and detection of chromosomal and extrachromosomal DNA of mycoplasmalike organisms associated with witches'-broom disease of pigeon pea in Florida. Mol Plant-Microbe Interact 4, 300-307.

57. Hibben, C. R., Sinclair, W. A., Davis, R. E. \& Alexander, J. H. (1991). Relatedness of mycoplasmalike organisms associated with ash yellows and lilac witches'-broom. Plant Dis 75, 1227-1230.

58. International Committee on Systematic Bacteriology Subcommittee on the Taxonomy of Mollicutes (1993). Minutes of the interim meetings, 1 and 2 August, 1992, Ames, lowa. Int $J$ Syst Bacteriol 43, 394-397.

59. Jagoueix, S., Bové, J. M. \& Garnier, M. (1994). The phloemlimited bacterium of greening disease of citrus is a member of the $\alpha$ subdivision of the Proteobacteria. Int $J$ Syst Bacteriol 44, 379-386.

60. Jarausch, W., Saillard, C., Dosba, F. \& Bové, J. M. (1994). Differentiation of mycoplasmalike organisms (MLOs) in European fruit trees by PCR using specific primers derived from the sequence of a chromosomal fragment of the apple proliferation MLO. Appl Environ Microbiol 60, 2916-2923.

61. Jomantiene, R., Davis, R. E., Maas, J. \& Dally, E. L. (1996). Phytoplasmas associated with disease of strawberry in Florida. Phytopathology 86, S123.

62. Jomantiene, R., Davis, R. E., Maas, J. \& Dally, E. L. (1998). Classification of new phytoplasmas associated with diseases of strawberry in Florida based on analysis of $16 \mathrm{~S}$ rRNA and ribosomal protein gene operon sequences. Int $J$ Syst Bacteriol 48, 269-277.

63. Keane, G., Edwards, A. \& Clark, M. F. (1996). Differentiation of group 16SrI-B aster yellows phytoplasmas with monoclonal antibodies. In 1996 BCPC Symposium Proceedings No. 65: Diagnostics in Crop Production, pp. 263-268.

64. Kirkpatrick, B. C., Fisher, G. F., Fraser, J. D. \& Purcell, A. H. (1990). Epidemiological and phylogenetic studies on western-X disease mycoplasmalike organisms. In Recent Advances in Mycoplasmology, pp. 288-297. Edited by G. H. Stanek, G. H. Casell, J. G. Tully \& R. F. Whitcomb. Stuttgart: Fisher Verlag.

65. Kirkpatrick, B. C. \& Smart, C. D. (1995). Phytoplasmas: can phylogeny provide the means to understand pathogenicity? In Advances in Botanical Research, pp. 188-212. Edited by J. H. Andrews \& I. C. Tommerup. New York: Academic Press.

66. Kirkpatrick, B. C., Smart, C. D., Gardner, S. L. \& 9 other authors (1994). Phylogenetic relationships of plant pathogenic MLOs established by $16 / 23 \mathrm{~S}$ rDNA spacer sequences. IOM Lett 3, 228-229.

67. Kirkpatrick, B. C., Stenger, D. C., Morris, T. J. \& Purcell, A. H. (1987). Cloning and detection of DNA from a nonculturable plant pathogenic mycoplasma-like organism. Science $\mathbf{2 3 8}$, 197-200.

68. Kison, H., Schneider, B. \& Seemüller, E. (1994). Restriction fragment length polymorphisms within the apple proliferation mycoplasmalike organism. $J$ Phytopathol 141, 395-401.

69. Ko, H. C. \& Lin, C. P. (1994). Development and application of 
cloned DNA probes for a mycoplasmalike organism associated with sweet potato witches'-broom. Phytopathology 84, 468-473.

70. Kunkel, L. O. (1926). Studies on aster yellows. Am J Bot 23, 646-705.

71. Kuske, C. R. \& Kirkpatrick, B. C. (1992). Phylogenetic relationships between the western aster yellows mycoplasmalike organisms and other prokaryotes established by 16S rRNA gene sequence. Int J Syst Bacteriol 42, 226-233.

72. Kuske, C. R., Kirkpatrick, B. C., Davis, M. J. \& Seemüller, E. (1991). DNA hybridization between western aster yellows mycoplasmalike organism plasmids and extrachromosomal DNA from other plant pathogenic mycoplasmalike organisms. Mol Plant-Microbe Interact 4, 75-80.

73. Lee, I.-M., Bartoszyk, I. M., Gundersen-Rindal, D. E. \& Davis, R. E. (1997). Phylogeny and classification of bacteria in the genera Clavibacter and Rathayibacter on the basis of $16 \mathrm{~S}$ rRNA gene sequence analyses. Appl Environ Microbiol 63, 2631-2636.

74. Lee, I.-M., Bertaccini, A., Vibio, M. \& Gundersen, D. E. (1995). Detection of multiple phytoplasmas in perennial fruit trees with decline symptoms in Italy. Phytopathology $\mathbf{8 5}$, 728-735.

75. Lee, I.-M., Bertaccini, A., Vibio, M., Gundersen, D. E., Davis, R. E., Mittempergher, L., Conti, M. \& Gennari, F. (1995). Detection and characterization of phytoplasmas associated with disease in Ulmus and Rubus in northern and central Italy. Phytopathol Mediterr 34, 174-183.

76. Lee, I.-M. \& Davis, R. E. (1988). Detection and investigation of genetic relatedness among aster yellows and other mycoplasmalike organisms by using cloned DNA and RNA probes. Mol Plant-Microbe Interact 1, 303-310.

77. Lee, I.-M. \& Davis, R. E. (1992). Mycoplasmas which infect plants and insects. In Mycoplasmas: Molecular Biology and Pathogenesis, pp. 379-390. Edited by J. Maniloff, R. N. McElhansey, L. R. Finch \& J. B. Baseman. Washington, DC: American Society for Microbiology.

78. Lee, I.-M., Davis, R. E., Chen, T.-A., Chiykowski, L. N., Fletcher, J., Hiruki, C. \& Schaff, D. A. (1992). A genotype-based system for identification and classification of mycoplasmalike organisms (MLOs) in the aster yellows MLO strain cluster. Phytopathology 82, 977-986.

79. Lee, I.-M., Davis, R. E. \& Hiruki, C. (1991). Genetic relatedness among clover proliferation mycoplasmalike organisms (MLOs) and other MLOs investigated by nucleic acid hybridization and restriction fragment length polymorphism analyses. Appl Environ Microbiol 57, 3565-3569.

80. Lee, I.-M., Davis, R. E., Sinclair, W. A., DeWitt, N. D. \& Conti, M. (1993). Genetic relatedness of mycoplasmalike organisms detected in Ulmus spp. in USA and Italy by means of DNA probes and polymerase chain reactions. Phytopathology $\mathbf{8 3}$, 829-833.

81. Lee, I.-M., Gundersen, D. E., Davis, R. E. \& Chiykowski, L. N. (1992). Identification and analysis of a genomic strain cluster of mycoplasmalike organisms associated with Canadian peach (eastern) X-disease, western X-disease, and clover yellow edge. $J$ Bacteriol 174, 6694-6698.

82. Lee, I.-M., Gundersen, D. E., Hammond, R. W. \& Davis, R. E. (1994). Use of mycoplasmalike organism (MLO) groupspecific oligonucleotide primers for nested-PCR assays to detect mixed-MLO infections in a single host plant. Phytopathology 84, 559-566.
83. Lee, I.-M., Hammond, R. W., Davis, R. E. \& Gundersen, D. E. (1993). Universal amplification and analysis of pathogen $16 \mathrm{~S}$ rDNA for classification and identification of mycoplasmalike organisms. Phytopathology 83, 834-842.

84. Lee, I.-M., Klopmeyer, M., Bartoszyk, I. M., GundersenRindal, D. E., Chou, S., Thomson, K. L. \& Eisenreich, R. (1997). Phytoplasma induced free-branching in commercial poinsettia cultivars. Nature Biotechnol 15, 178-182.

85. Lee, I.-M., Pastore, M., Vibio, M., Danielli, A., Attathom, S. Davis, R. E. \& Bertaccini, A. (1997). Detection and characterization of phytoplasma associated with annual blue grass (Poa annua) white leaf in southern Italy. Eur J Plant Pathol 103, 251-254.

86. Lee, I.-M., Zhu, S., Gundersen, D. E., Zhang, C. \& Hadidi, A. (1995). Detection and identification of a new phytoplasma associated with cherry lethal yellows in China. Phytopathology 85, 1179.

87. Liefting, L. W., Andersen, M. T., Beever, R. E., Gardner, R. C. \& Foster, L. S. (1996). Sequence heterogeneity in the two $16 \mathrm{~S}$ rRNA genes of Phormium yellow leaf phytoplasma. Appl Environ Microbiol 62, 3133-3139.

88. Lim, P. O. \& Sears, B. B. (1989). 16S rRNA sequence indicates that plant-pathogenic mycoplasmalike organisms are evolutionarily distinct from animal mycoplasmas. $J$ Bacteriol 171, 5901-5906.

89. Lim, P. O. \& Sears, B. B. (1991). DNA sequence of the ribosomal protein genes $r p / 2$ and $r p s 19$ from a plantpathogenic mycoplasmalike organism. FEMS Microbiol Lett 84, 71-74.

90. Lim, P. O. \& Sears, B. B. (1992). Evolutionary relationships of a plant-pathogenic mycoplasmalike organism and Acholeplasma laidlawii deduced from two ribosomal protein gene sequences. $J$ Bacteriol 174, 2606-2611.

91. Lin, C. P. \& Chen, T.-A. (1985). Monoclonal antibodies against the aster agent. Science 227, 1233-1235.

92. Loi, N., Carraro, L., Musetti, R., Pertot, I. \& Osler, R. (1995). Dodder transmission of two different MLOs from plum trees affected by a 'leptonecrosis'. Acta Hortic 386, 465-470.

93. Lorenz, K. H., Schneider, B., Ahrens, U. \& Seemüller, E. (1995). Detection of the apple proliferation and pear decline phytoplasmas by PCR amplification of ribosomal and nonribosomal DNA. Phytopathology 85, 771-776.

94. Maixner, M., Ahrens, U. \& Seemüller, E. (1994). Detection of mycoplasmalike organisms associated with a yellows disease grapevine in Germany. $J$ Phytopathol 142, 1-10.

95. Maixner, M., Ahrens, U. \& Seemüller, E. (1995). Detection of the German grapevine yellows (Vergibungskrankheit) MLO in grapevine, alternative hosts and a vector by a specific PCR procedure. Eur J Plant Pathol 101, 241-250.

96. Marcone, C., DiSerio, F. \& Ragozzino, A. (1995). Peach rosette: a disease associated with mycoplasma-like organisms. Acta Hortic 386, 471-479.

97. Marcone, C., Ragozzino, A., Schneider, B., Lauer, U., Smart, C. D. \& Seemüller, E. (1996). Genetic characterization and classification of two phytoplasmas associated with spartium witches'-broom disease. Plant Dis 80, 365-371.

98. Marcone, C., Ragozzino, A. \& Seemüller, E. (1996). Detection and differentiation of phytoplasmas of the elm yellows and apple proliferation groups in diseased shrubs, shade trees, and forest trees in Europe. IOM Lett 4, 214.

99. Marcone, C., Ragozzino, A. \& Seemüller, E. (1996). Detection 
of an elm yellows-related phytoplasma in eucalyptus trees affected by little-leaf disease in Italy. Plant Dis 80, 669-673.

100. Mäurer, R., Seemüller, E. \& Sinclair, W. A. (1993). Genetic relatedness of mycoplasmalike organisms affecting elm, alder, and ash in Europe and North America. Phytopathology 83, 971-976.

101. McCoy, R. E., Caudwell, A., Chang, C. J. \& 16 other authors (1989). Plant diseases associated with mycoplasmalike organisms. In The Mycoplasmas, vol. 5, pp. 545-560. Edited by R. F. Whitcomb \& J. G. Tully. New York: Academic Press.

102. Murray, R. G. E. \& Schleifer, K. H. (1994). Taxonomic notes: a proposal for recording the properties of putative taxa of prokaryotes. Int J Syst Bacteriol 44, 174-176.

103. Nakashima, K., Kato, S., Iwanami, S. \& Murata, N. (1993). DNA probes reveal relatedness of rice yellow dwarf mycoplasmalike organisms (MLOs) and distinguish them from other MLOs. Appl Environ Microbiol 59, 1206-1212.

104. Namba, S., Kato, S., Iwanami, S., Oyaizu, H., Shiozawa, H. \& Tsuchizaki, T. (1993). Detection and differentiation of plant-pathogenic mycoplasmalike organisms using polymerase chain reaction. Phytopathology 83, 786-791.

105. Namba, S., Oyaizu, H., Kato, S., Iwanami, S. \& Tsuchizaki, T. (1993). Phylogenetic diversity of phytopathogenic mycoplasmalike organisms. Int $J$ Syst Bacteriol 43, 461 467.

106. Nei, M. \& Li, W.-H. (1979). Mathematical model for studying genetic variation in terms of restriction endonucleases. Proc Natl Acad Sci USA 76, 5269-5273.

107. Okuda, S., Prince, J. P., Davis, R. E., Dally, E. L., Lee, I.-M. \& Mogen, B. (1997). Two groups of phytoplasmas from Japan distinguished on the basis of amplification and restriction analysis of 16S rDNA. Plant Dis 81, 301-305.

108. Padovan, A. C., Gibb, K. S., Bertaccini, A., Bonfiglioli, R. E., Magnet, P. A. \& Sears, B. B. (1995). Molecular detection of the Australian grapevine yellows phytoplasma and comparison with grapevine yellows phytoplasmas from Italy. Aust J Grape Wine Res 1, 25-31.

109. Poggi-Pollini, C., Giunchedi, L., Seemüller, E., Filippini, G. \& Vindimian, G. (1995). Etiological studies of apple rubbery wood disease. Acta Hortic 385, 503-505.

110. Prince, J. P., Davis, R. E., Wolf, T. K., Lee, I.-M., Mogen, B. D., Dally, E. L., Bertaccini, A., Credi, R. C. \& Barba, M. (1993). Molecular detection of diverse mycoplasmalike organisms (MLOs) associated with grapevine yellows and their classification with aster yellows, X-disease, and elm yellows MLOs. Phytopathology 83, 1130-1137.

111. Rogall, T., Wolters, J., Flohr, T. \& Böttger, E. C. (1990). Towards a phylogeny and definition of species at the molecular level within the genus Mycobacterium. Int $J$ Syst Bacteriol 40, 323-330.

112. Sambrook, J., Fritsch, E. F. \& Maniatis, T. (1989). Molecular Cloning: a Laboratory Manual, 2nd edn. Cold Spring Harbor, NY: Cold Spring Harbor Laboratory.

113. Schaff, D. A., Lee, I.-M. \& Davis, R. E. (1992). Sensitive detection and identification of mycoplasmalike organisms by polymerase chain reactions. Biochem Biophys Res Commun 186, 1503-1509.

114. Schneider, B., Ahrens, U., Kirkpatrick, B. C. \& Seemüller, E. (1993). Classification of plant-pathogenic mycoplasmalike organisms using restriction-site analysis of PCRamplified 16S rDNA. J Gen Microbiol 139, 519-527.

115. Schneider, B., Cousin, M. T., Klinkong, S. \& Seemüller, E.
(1995). Taxonomic relatedness and phylogenetic positions of phytoplasmas associated with diseases of faba bean, sunhemp, sesame, soybean, and eggplant. Z Pflanzenkr Pflanzenschutz 102, 225-232

116. Schneider, B. \& Gibb, K. S. (1997). Detection of phytoplasma in decline pears in southern Australia. Plant Dis 81. $254-258$.

117. Schneider, B. \& Seemüller, E. (1994). Presence of two sets of ribosomal genes in phytopathogenic mollicutes. Appl Environ Microbiol 141, 173-185.

118. Schneider, B., Seemüller, E., Smart, C. D. \& Kirkpatrick, B. C. (1995). Phylogenetic classification of plant pathogenic mycoplasmalike organisms or phytoplasmas. In Molecular and Diagnostic Procedures in Mycoplasmology, vol. I, pp. 369-380. Edited by R. Razin \& J. G. Tully. San Diego: Academic Press.

119. Sears, B. B. \& Kirkpatrick, B. C. (1994). Unveiling the evolutionary relationships of plant-pathogenic mycoplasmalike organisms. ASM News 60, 307-312.

120. Sears, B. B., Lim, O., Holland, N., Kirkpatrick, B. C. \& Klomparens, K. L. (1989). Isolation and characterization of DNA from a mycoplasma-like organism. Mol PlantMicrobe Interact 2, 175-180.

121. Seemüller, E., Schneider, B., Mäurer, R. \& 8 other authors (1994). Phylogenetic classification of phytopathogenic mollicutes by sequence analysis of $16 \mathrm{~S}$ ribosomal DNA. Int J Syst Bacteriol 44, 440-446.

122. Shaw, M. E., Kirkpatrick, B. C. \& Golino, D. A. (1991). Causal agent of tomato big bud disease in California is the beet leafhopper-transmitted virescence agent. Phytopathology 81, 1210.

123. Shiomi, T. \& Sugiura, M. (1984). Differences among Macrosteles orientalis-transmitted MLO, potato purpletop wilt in Japan, and aster yellows MLO from USA. Ann Phytopathol Soc Jpn 50, 455-460.

124. Shiomi, T. \& Sugiura, M. (1984). Grouping of mycoplasmalike organisms transmitted by the leafhopper vector, Macrosteles orientalis Virvaste, based on host range. Ann Phytopathol Soc Jpn 50, 149-157.

125. Sinclair, W. A. (1995). Epidemiology of a slow-decline phytoplasmal disease: ash yellows on old-field sites in New York State. Phytopathology 85, 123-128.

126. Sinclair, W. A., Griffiths, H. M. \& Lee, I.-M. (1994). Mycoplasmalike organisms as causes of slow growth and decline of trees and shrubs. $J$ Aboric 20, 176-189.

127. Sinclair, W. A., luli, R. J., Dyer, A. T., Marshall, P. T., Matteoni, J. A., Hibben, C. R., Stanosz, G. R. \& Burns, B. S. (1990). Ash yellows: geographic range and association with decline of white ash. Plant Dis 74, 604-607.

128. Smart, C. D., Schneider, B., Blomquist, C. L., Guerra, L. J., Harrison, N. A., Ahrens, U., Lorenz, K. H., Seemüller, E. \& Kirkpatrick, B. C. (1996). Phytoplasma-specific PCR primers based on sequences of $16 \mathrm{~S}-23 \mathrm{~S}$ rRNA spacer region. Appl Environ Microbiol 62, 2988-2993.

129. Stackebrandt, E. \& Goebel, B. M. (1994). Taxonomic note: a place for DNA-DNA reassociation and $16 \mathrm{~S}$ rRNA sequence analysis in the present species definition in bacteriology. Int J Syst Bacteriol 44, 846-849.

130. Toth, K. F., Harrison, N. A. \& Sears, B. B. (1994). Phylogenetic relationships among members of the class Mollicutes deduced from $r p s 3$ gene sequences. Int $J$ Syst Bacteriol 44, 119-124. 
131. Vandamme, P., Pot, B., Gillis, M., Vos, P. De, Kersters, K. \& Swings, J. (1996). Polyphasic taxonomy, a consensus approach to bacterial systematics. Microbiol Rev 60, 407 -438 .

132. Vega, F. E., Davis, R. E., Barbosa, P., Dally, E. L., Purcell, A. H. \& Lee, I.-M. (1993). Detection of a plant pathogen in a nonvector insect species by the polymerase chain reaction. Phytopathology 83, 621-624.

133. Vibio, M., Bertaccini, A., Lee, I.-M., Davis, R. E. \& Clark, M. F. (1994). Characterization of aster yellows and related European mycoplasmalike organisms maintained in periwinkle plants and shoot-tip culture. IOM Lett 3, 297-298.

134. Vibio, M., Bertaccini, A., Lee, I.-M., Davis, R. E. \& Clark, M. F. (1996). Differentiation and classification of aster yellows and related European phytoplasmas. Phytopathol Mediterr 35, 33-42.

135. Vibio, M., Bertaccini, A., Lee, I.-M., Davis, R. E., Minucci, C. \& Milne, R. G. (1994). Etiology of lettuce yellows in Italy: genetic characterization of associated mycoplasmalike organisms. Phytopathol Mediterr 33, 179-186.

136. Wayne, L. G., Brenner, D. J., Colwell, R. R. \& 9 other authors (1987). International Committee on Systematic Bacteriology. Report of the ad hoc committee on reconciliation of approaches to bacterial systematics. Int $J$ Syst Bacteriol 37. 463-464.

137. Weisburg, W. G., Tully, J. G., Rose, D. L. \& 9 other authors (1989). A phylogenetic analysis of the mycoplasmas: basis for their classification. $J$ Bacteriol 171, 6455-6467.

138. Whitcomb, R. F. (1994). Systematics of prokaryotes and eukaryotes: a search for synthesis. Klieneberger-Nobel award lecture, 10th Congress of IOM, Bordeaux, France.

139. Wisotzkey, J. D., Jurtshuk, P., Jr \& Fox, G. E. (1990). PCR amplification of 16 rDNA from lyophilized cell culture facilitate studies in microbial systematics. Curr Microbiol 21, 325-327.

140. Woese, C. R. (1987). Bacterial evolution. Microbiol Rev 51 , 221-271.

141. Woese, C. R., Maniloff, J. \& Zablen, L. B. (1980). Phylogenetic analysis of the mycoplasmas. Proc Natl Acad Sci USA 77, 494498.

142. Xu, B. Y. \& Chen, T.-A. (1996). Cranberry false blossom disease in New Jersey. Phytopathology 86, S125.

143. Yoshikada, N., Nakamura, H., Sahashi, N., Kubono, T., Katsube, K., Shoji, T. \& Takahashi, T. (1994). Amplification and nucleotide sequences of ribosomal protein and $16 \mathrm{~S}$ rRNA genes of mycoplasma-like organism associated with paulownia witches'-broom. Ann Phytopathol Soc Jpn 60, 569-575.

144. Zhu, S. F., Lee, I.-M., Gundersen, D. E., Zhang, C. L. \& Hadidi, A. (1996). Phytoplasmas associated with cherry lethal yellows and jujube witches'-broom in China represent a new Candidatus subspecies level taxon. IOM Lett 4, 218.

145. Zreik, L., Carle, P., Bové, J. M. \& Garnier, M. (1995). Characterization of the mycoplasmalike organism associated with witches'-broom disease of lime and proposition of a Candidatus taxon for the organism, 'Candidatus Phytoplasma aurantifolia'. Int $J$ Syst Bacteriol 45, 449-453. 
